\title{
Economic Geology
}

\author{
BULLETIN OF THE SOCIETY OF ECONOMIC GEOLOGISTS
}

VOL. 111

March-April

No. 2

\section{Cerro Quema (Azuero Peninsula, Panama): Geology, Alteration, Mineralization, and Geochronology of a Volcanic Dome-Hosted High Sulfidation Au-Cu Deposit}

\author{
Isaac Corral, ${ }^{1,2,+}$ Esteve Cardellach, ${ }^{1}$ Mercè Corbella, ${ }^{1}$ Àngels Canals, ${ }^{3}$ David Gómez-Gras, ${ }^{1}$ \\ Albert Griera, ${ }^{1}$ and Michael A. Cosca ${ }^{4}$ \\ ${ }^{1}$ Departament de Geologia, Universitat Autònoma de Barcelona, 08193 Barcelona, Spain \\ ${ }^{2}$ Economic Geology Research Centre (EGRU), College of Science, Technology and Engineering, \\ James Cook University, Townsville, QLD 4811, Australia \\ ${ }^{3}$ Facultat de Geologia, Universitat de Barcelona, 08028 Barcelona, Spain \\ ${ }^{4}$ U.S. Geological Survey, Denver, CO 80225 \\ Abstract
}

\begin{abstract}
Cerro Quema (Azuero Peninsula, southwest Panama) is a high sulfidation epithermal Au-Cu deposit hosted by a dacite dome complex of the Río Quema Formation (late Campanian to Maastrichtian), a fore-arc basin sequence. Mineral resource estimates (indicated + inferred) are $30.86 \mathrm{Mt}$ at $0.73 \mathrm{~g} / \mathrm{t} \mathrm{Au}$, containing 728,000 oz Au (including $76.900 \mathrm{oz}$ Au equiv of $\mathrm{Cu}$ ore). Hydrothermal alteration and mineralization are controlled by an E-trending regional fault system. Hydrothermal alteration consists of an inner zone of vuggy quartz with locally developed advanced argillic alteration, enclosed by a well-developed zone of argillic alteration, grading to an external halo of propylitic alteration. Mineralization produced disseminations and microveinlets of pyrite and minor chalcopyrite, enargite, and tennantite, with traces of sphalerite, crosscut by late-stage base metal veins. New ${ }^{40} \mathrm{Ar} /{ }^{39} \mathrm{Ar}$ data of igneous rocks combined with biostratigraphic ages of the volcanic sequence indicate a maximum age of lower Eocene ( 55-49 Ma) for the Cerro Quema deposit. It was probably triggered by the emplacement of an underlying porphyry-like intrusion associated with the Valle Rico batholith. The geologic model suggests that in the Azuero Peninsula high sulfidation epithermal mineralization occurs in the Cretaceous-Paleogene fore arc. This consideration should be taken into account when exploring for this deposit type in similar geologic terranes.
\end{abstract}

\section{Introduction}

South Central America is a region characterized by a longlived intraoceanic subduction zone with a volcanic arc active since the Late Cretaceous (e.g., Lissinna, 2005; Buchs et al., 2010, 2011a). It displays many characteristics of zones where epithermal, porphyry copper, and volcanogenic massive sulfide (VMS) deposits are found around convergent plate boundaries (e.g., Roberts and Irving, 1957; Levy, 1970; Ferencic, 1971; Weyl, 1980; Nelson, 2007).

High sulfidation epithermal deposits (Hedenquist et al., $2000)$ are commonly hosted by subaerial, calc-alkaline volcanic rocks that formed at convergent margins, generally within island or continental arcs as a direct result of plate subduction (Sillitoe, 1993, 2010; Arribas and Tosdal, 1994; Cooke and Simmons, 2000). Mineralization styles related to high sulfidation deposits display a wide variety, including veins, hydrothermal breccia bodies, stockworks, and dissemination or replacements (Arribas, 1995). A distinguishing feature of this deposit type is the presence of alteration halos (grading from

†Corresponding author: e-mail, i.corral.geo@gmail.com the fluid conduit outward) characterized by quartz \pm alunite \pm pyrophyllite \pm dickite \pm kaolinite \pm illite, and montmorillonite \pm chlorite (Steven and Ratté, 1960; Stoffregen, 1987; Arribas, 1995; Hedenquist et al., 2000). The most common geologic setting documented for this deposit type is a volcanic dome complex; however, they may also occur in a central-vent volcano setting and in a spatial association with maar-diatremes or calderas (Sillitoe et al., 1984; Arribas, 1995; Sillitoe, 1999; Hedenquist et al., 2000). Furthermore, submarine high sufidation epithermal $\mathrm{Au}-\mathrm{Cu}$ deposits have been reported in the Izu-Bonin-Mariana arc, the Tonga-Kermadec arc, and the Bismark archipelago (e.g., Binns and Scott, 1993; Hannington and Herzig, 1993; de Ronde et al., 2003; Embley et al., 2004).

In Panama, gold and copper are the most economically important metals, and they are mainly hosted by epithermal (e.g., Cana, Santa Rosa, and Cerro Quema deposits; Woakes, 1923; Wleklinski, 1969; White, 1993; Nelson, 1995, 2007; Corral et al., 2011a) and porphyry copper deposits (e.g., Petaquilla and Cerro Colorado, Kesler et al., 1977; Kesler, 1978; Nelson, 1995; Speidel, 2001). The present study focuses on the Cerro Quema deposit, located in the Azuero Peninsula, 
southwest Panama (Fig. 1A). This region hosts several epithermal deposits and prospects (e.g., Juan Diaz, Pitaloza, Las Minas, Cerro Viejo, Fig. 1B). Cerro Quema, considered one of the most promising $\mathrm{Au}-\mathrm{Cu}$ prospects in the country, is a structurally and lithologically controlled high sulfidation epithermal deposit, hosted by dacite domes, in a calc-alkaline volcanic arc environment (Corral et al., 2011a). Mineral resource estimates (indicated + inferred) are $30.86 \mathrm{Mt}$ at $0.73 \mathrm{~g} / \mathrm{t} \mathrm{Au}$, containing 728,000 oz Au, including $76.900 \mathrm{oz}$ (Au equiv) of Cu ore (Valiant et al., 2011; Puritch et al., 2012).

Hypogene sulfides at Cerro Quema deposit include pyrite, enargite, and tennantite. The associated hydrothermal alteration minerals include alunite, kaolinite-dickite, and pyrophyllite. All of these are diagnostic of a high sulfidation state and acidic hydrothermal conditions (Arribas, 1995). Although Cerro Quema shows characteristics of high sulfidation epithermal deposits, its age and geodynamic setting are not well understood. It has been interpreted to be a volcanic dome-hosted high sulfidation deposit related to fore-arc magmatism (Corral et al., 2011a; Corral, 2013), in contrast to the classical high sulfidation epithermal models (e.g., Hedenquist, 1987; Sillitoe, 1989, 1999; White, 1991; Hedenquist and Lowenstern, 1994; Arribas, 1995). Cerro Quema is hosted by fore-arc basin volcanosedimentary rocks that have been intruded by different plutonic rocks through time (Corral et al., 2011a).

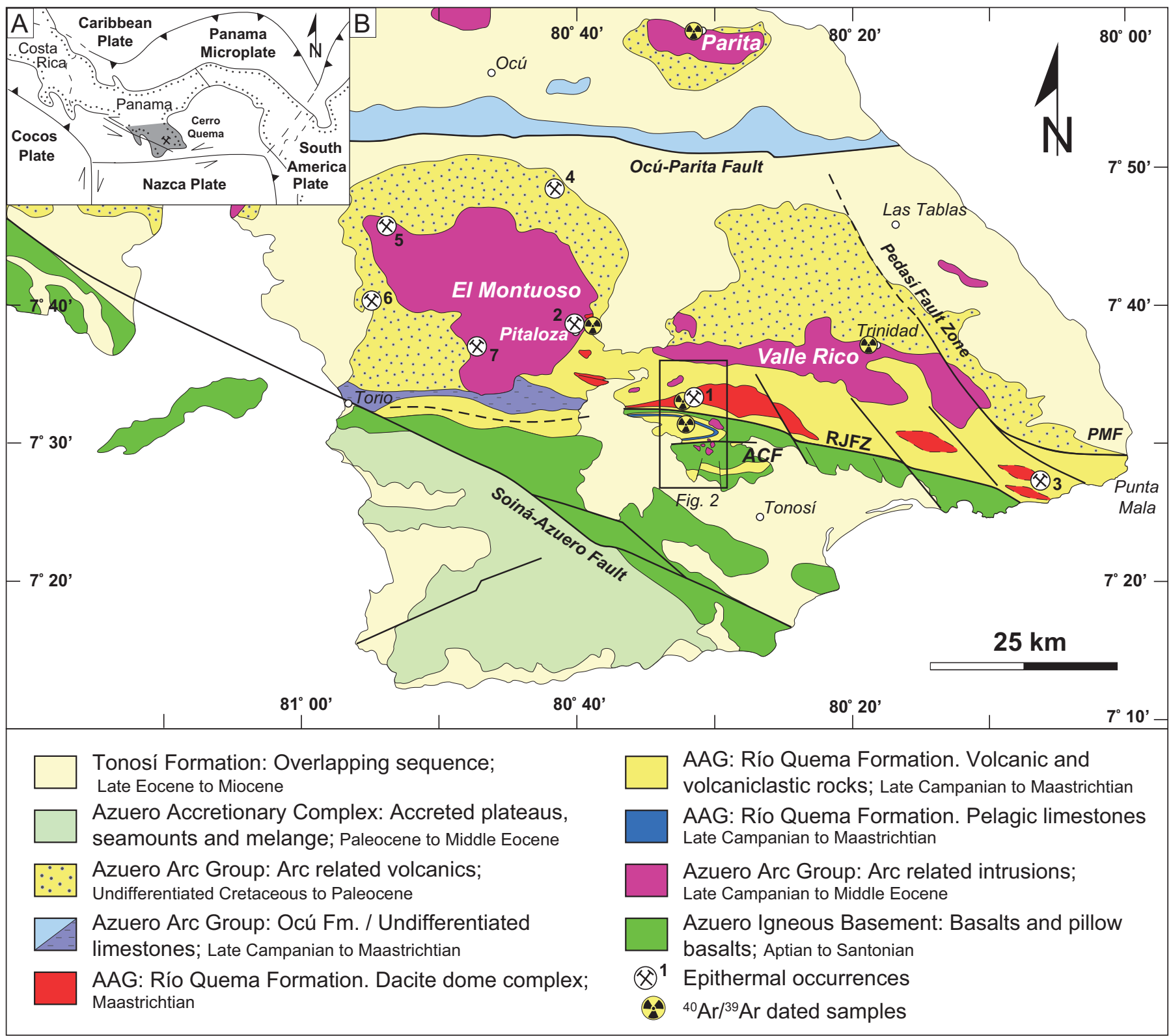

Fig. 1. A) Plate tectonic setting of south Central America. B) Simplified geologic map of the Azuero Peninsula with the main epithermal occurrences. AAG = Azuero Arc Group, ACF = Auga Clara fault, PMF = Punta Mala fault, RJFZ = Río Joaquín fault zone (after Dirección General de Recursos Minerales, 1976; Buchs et al., 2011a; Corral et al., 2011a, 2013; Corral, 2013). 1) Cerro Quema, 2) Pitaloza, 3) Juan Díaz, 4) Las Minas, 5) Quebrada Barro, 6) Quebrada Iguana, 7) Cerro Viejo. 
We document the geologic setting, mineralogy, geochemistry, and ${ }^{40} \mathrm{Ar} /{ }^{39} \mathrm{Ar}$ geochronology of Cerro Quema. A geologic model is developed from these data that contributes to the understanding and exploration of high sulfidation $\mathrm{Au}-\mathrm{Cu}$ deposits in ancient and modern terranes, with similar geologic features.

\section{Geologic Setting}

\section{Regional geology}

Panama, located in south Central America, is the youngest segment of the land bridge between the North and South American plates. It is a tectonic block that lies at the junction of the Caribbean, South American, Cocos, and Nazca plates (e.g., Duque-Caro, 1990; Kellogg et al., 1995; Harmon, 2005). A volcanic arc developed during the Late Cretaceous as a result of the subduction of the ancient Farallon plate (nowadays Cocos and Nazca plates) beneath the Caribbean plate. Volcanic arc magmatism continued until the Miocene ( 23 Ma; Barckhausen et al., 2001; Werner et al., 2003; Lonsdale, 2005; Buchs et al., 2009, 2010; Pindell and Kennan, 2009; Wörner et al., 2009). The accretion and obduction of seamounts and oceanic plateaus (middle Eocene; Buchs et al., 2010) and the collision of the Panamanian volcanic arc with Colombia during the middle to late Miocene (e.g., Keigwin, 1978; Trenkamp et al., 2002; Coates et al., 2004; Barat et al., 2012,2014 ) produced a change in the subduction direction and the migration of the volcanic arc toward the north (Lissinna et al., 2002; Lissinna, 2005). The Cordillera Central in north Panama is the present-day expression of the active Panamanian volcanic arc.

\section{Geology of the Azuero Peninsula and the Cerro Quema deposit}

The Azuero Peninsula is composed of igneous basement overlain by fore-arc sediments (Buchs et al., 2011). This region contains volcanic, plutonic, sedimentary, and volcaniclastic rocks ranging in age from $\sim 98$ to $\sim 40 \mathrm{Ma}$ (Del Giudice and Recchi, 1969; Bourgois et al., 1982; Kolarsky et al., 1995; Lissinna, 2005; Wörner et al., 2009; Buchs et al., 2010; Wegner et al., 2011; Corral et al., 2013).

Five distinct rock associations have been recognized in the Azuero Peninsula (Fig. 1B):

1. The Azuero igneous basement is composed of Late Cretaceous (Aptian to Santonian) basalts and pillow basalts with geochemical affinities similar to the Caribbean large igneous province, interpreted as the arc basement (Del Giudice and Recchi, 1969; Kolarsky et al., 1995; Hauff et al., 2000; Hoernle et al., 2002, 2004; Lissinna, 2005; Buchs et al., 2009; Corral et al., 2011a).

2. The Azuero primitive volcanic arc, a nonmappable unit at regional scale, consists of tholeiitic basalts and volcaniclastic rocks, locally interbedded with late Campanian-Maastrichtian hemipelagic limestones, which are equivalent to the proto-arc defined by Buchs et al. (2010). It corresponds to the initial stages of arc volcanism.

3. The Azuero Arc Group consists of volcanosedimentary, volcanic, and arc-related intrusive rocks with calc-alkaline character, representing the Cretaceous and Paleogene volcanic arcs (Lissinna, 2005; Wörner et al., 2009; Buchs et al., 2010, 2011a; Wegner et al., 2011; Corral et al., 2011a, 2013).

4. The Tonosí Formation, a middle Eocene to early Miocene sedimentary sequence, unconformably overlies the older units (Recchi and Miranda, 1977; Kolarsky et al., 1995; Krawinkel and Seyfried, 1994; Krawinkel et al., 1999).

5. The Azuero accretionary complex consists of Paleocene to middle Eocene seamounts, oceanic plateaus, and mélanges accreted along the ancient subduction trench (Hoernle et al., 2002; Lissinna, 2005; Hoernle and Hauff, 2007; Buchs et al., 2011b).

The Azuero Peninsula is transected by several regionalscale subvertical faults (Fig. 1B). These include the NWtrending Soná-Azuero fault zone, the E-trending Ocú-Parita fault, and the Río Joaquín fault zone (Kolarsky et al., 1995; Buchs, 2008; Corral et al., 2011a, 2013). The Río Joaquín fault zone is $30 \mathrm{~km}$ in length, shows evidence for reverse dip-slip motion, and juxtaposed the Azuero igneous basement against the Azuero Arc Group (e.g., Río Quema Formation). Secondary NW-trending regional structures such as the Pedasí fault zone and the Punta Mala fault, both with a sinistral strike-slip motion, have disrupted the eastern Azuero Peninsula (Fig. 2). In the central Azuero Peninsula mesoscale open folds with SW-plunging fold axes and moderate limb dips indicate dextral transpression with dominant reverse dip-slip motion (Corral et al., 2011a, 2013).

The local stratigraphy was initially defined by two units (C.F. Horlacher, pers. comm., 1993): (1) the Ocú Formation, composed of limestones and volcanosedimentary rocks, and (2) the Quema Formation, composed of dacites and massive andesites. Corral et al. (2011a, 2013) used new field, geochemical, and biostratigraphic data to define a new lithostratigraphic unit, the Río Quema Formation (Fig. 3). This newly defined unit, which hosts the Cerro Quema deposit, is a volcanosedimentary sequence enclosed within the Azuero Arc Group. It is interpreted as the volcaniclastic apron of the Panamanian Cretaceous volcanic arc. The volcanic sequence is exposed from the central to southeastern Azuero Peninsula and represents the fore-arc basin, the region between the subduction trench and the magmatic arc (e.g., Stern et al., 2012). On the basis of biostratigraphic data, the volcanosedimentary sequence is late Campanian to Maastrichtian in age (Corral et al., 2013). The Río Quema Formation is subdivided into three units (Fig. 3). The lower unit contains andesitic lava flows and well-bedded crystal-rich sandstone to siltstone turbidites, interbedded with hemipelagic thin limestone beds. The limestone unit is a thick, light gray biomicritic hemipelagic limestone, interlayered with well-bedded cherts, thin-bedded turbidites, and fine ash layers. The upper unit consists of volcaniclastic sediments interlayered with massive to laminar andesitic lava flows, dacite domes, dacite hyaloclastites (Fig. 3B), and polymictic conglomerates. Dacites are characterized by quartz and hornblende phenocrysts (up to $5 \mathrm{~cm}$ in hornblende) and smaller plagioclase crystals in a microcrystalline quartz-feldspar groundmass. The total thickness of the Río Quema Formation is approximately 1,700 m. It overlies both the Azuero igneous basement (Fig. 3A) and the Azuero primitive volcanic arc, and is discordantly overlain by the Tonosí Formation (Fig. 3C). 


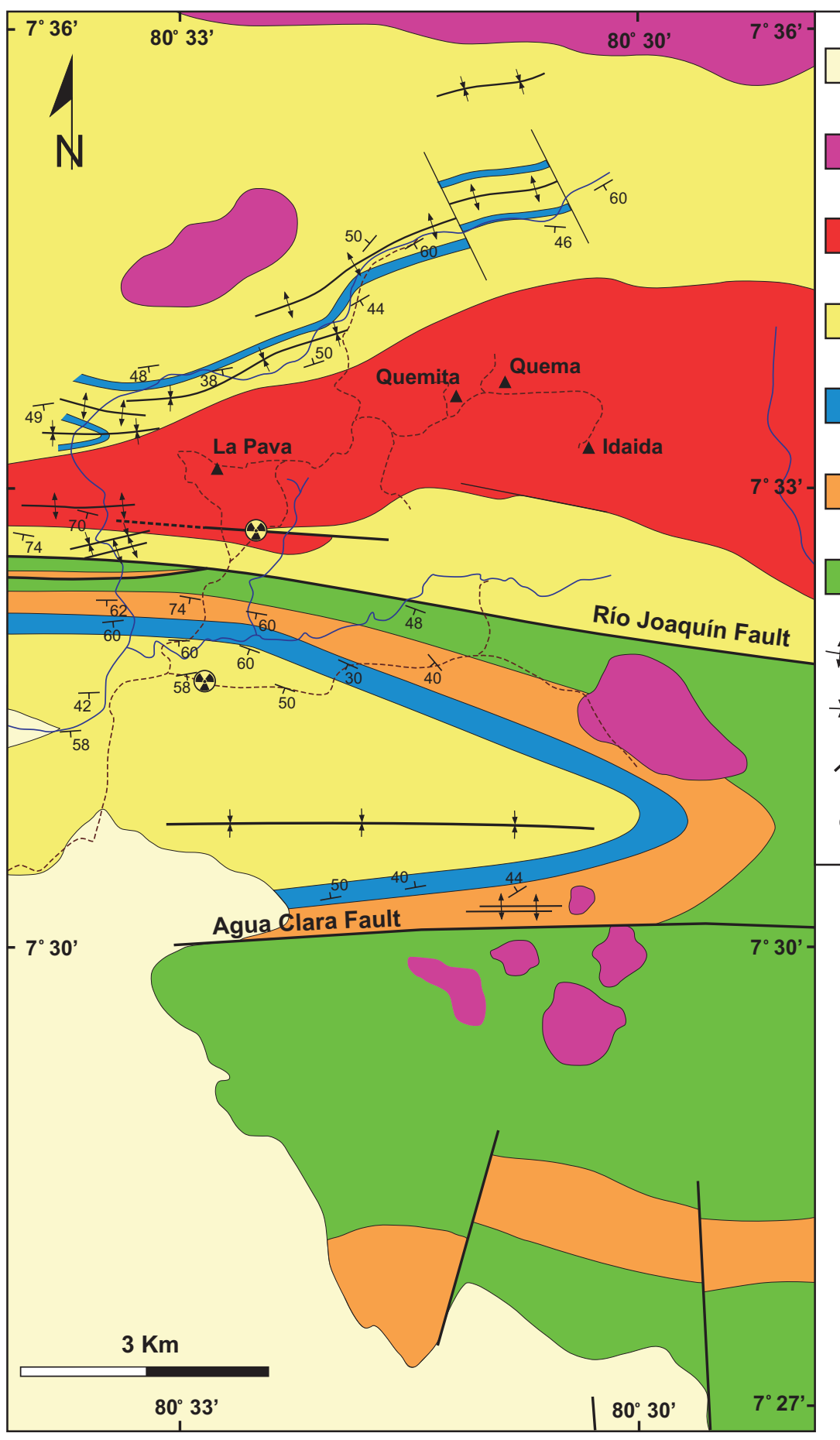

Tonosí Formation: reefal limestones, calcarenites, turbidites.

Late Eocene to Miocene

Valle Rico-like intrusions: quartz-diorites,

trachyandesites, diorites.

Late Paleocene to Middle Eocene

Río Quema Fm. Upper unit: dacite dome complex. Maastrichtian

Río Quema Fm. Upper unit: volcanic rocks, conglomerates and volcaniclastic rocks.

Late Campanian to Maastrichtian

Río Quema Fm. Limestone unit: pelagic to hemipelagic limestones.

Late Campanian to Maastrichtian

Río Quema Fm. Lower unit: volcanic and volcaniclastic rocks.

Late Campanian to Maastrichtian

Azuero Igneous Basement: basalts and pillow basalts.

Aptian to Santonian

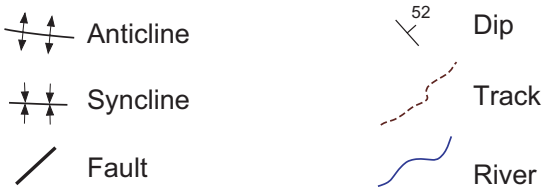

( Dated samples $\left({ }^{40} \mathrm{Ar} /{ }^{39} \mathrm{Ar}\right)$
Fig. 2. Simplified geologic map of Central Azuero Peninsula and location of the Cerro Quema Au-Cu deposit (after Corral et al., 2011a, 2013; Corral, 2013).
The Cerro Quema deposit is located in the center of the Azuero Peninsula. It covers an area of $\sim 20 \mathrm{~km}^{2}$ (Figs. 1B, 2) and is associated with an E-trending regional fault system, parallel to the Río Joaquín fault zone (Corral et al., 2011a). The deposit is hosted by the dacite dome complex of the Río Quema Formation and contains several orebodies. From east to west, these are Cerro Quema, Cerro Quemita, and La Pava (Fig. 4). Although mineralization and hydrothermal alteration persist to the east (e.g., Cerro Idaida, Pelona, and Peloncita), the economic potential of this zone is poorly known. Data from Cerro Idaida are presented below in order to complement the geologic characterization of Cerro Quema.

\section{Hydrothermal Alteration}

Wall-rock alteration at Cerro Quema was initially described by T. M. Leach (pers. comm., 1992) and, subsequently, by Corral et al. (2011a). We provide new data on hydrothermal alteration mineralogy and zoning based on field mapping and core 


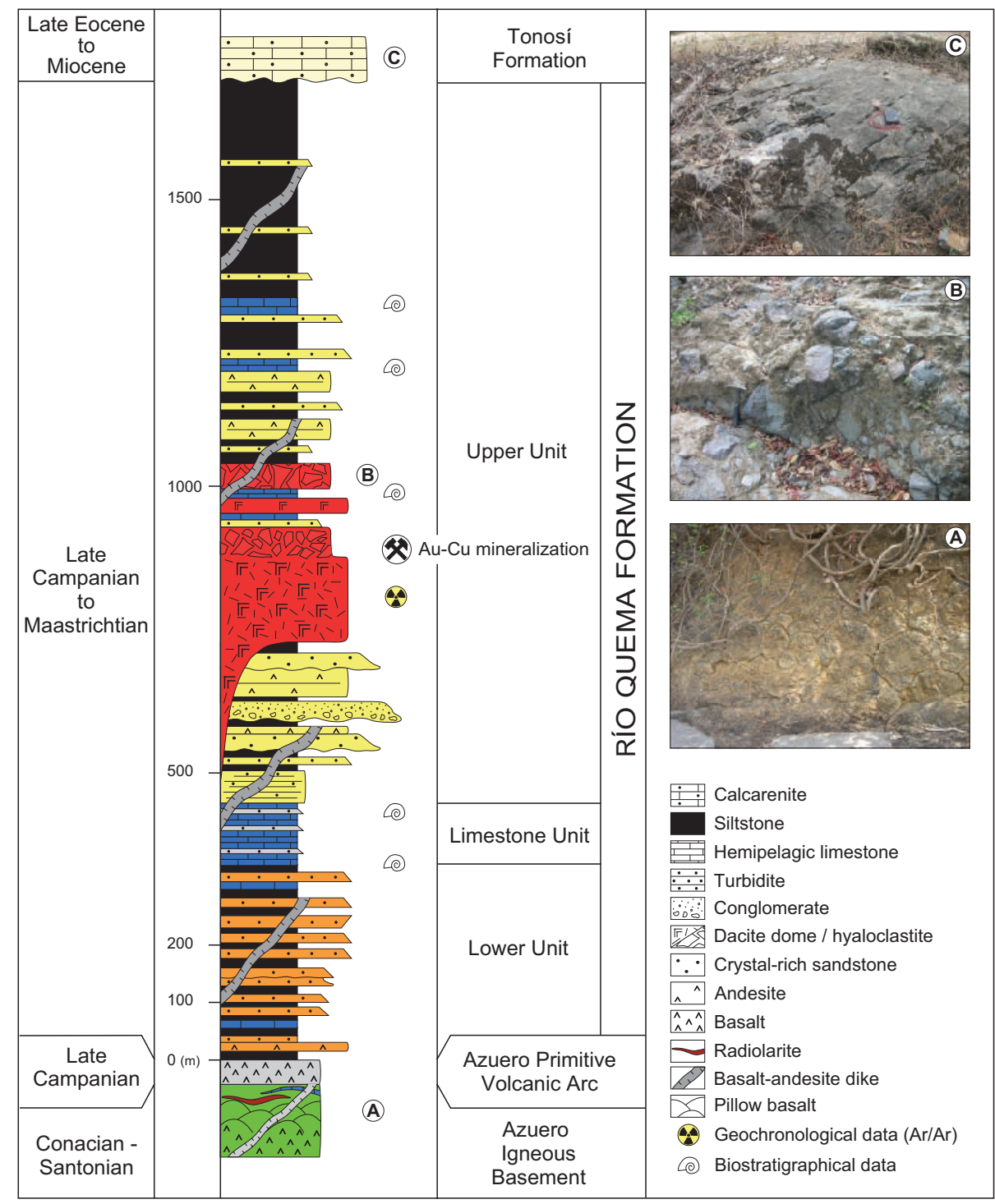

Fig. 3. Stratigraphic section of the Río Quema Formation indicating emplacement of the Cerro Quema Au-Cu deposit and biostratigraphic and geochronological data (after Corral et al., 2011a, 2013; Corral, 2013). A. Pillow basalts of the Azuero igneous basement at Los Ciruelos beach. B. Hyaloclastites of the dacite dome complex at Quema River. C. Calcarenites of the Tonosí Formation at Guerita River.

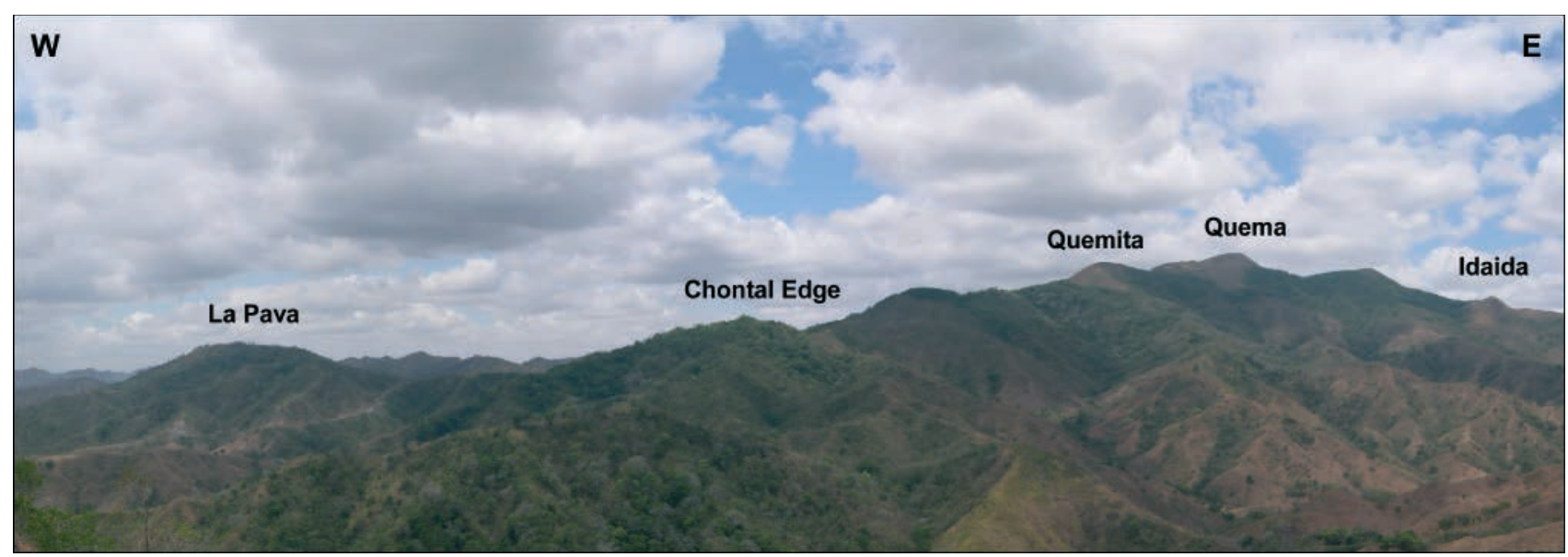

Fig. 4. Overview of Cerro Quema including La Pava, Cerro Quemita, Cerro Quema, and Cerro Idaida ore zones. 
logging, and on analysis of surface and drill core samples by petrographic microscope, X-ray diffraction (XRD), scanning electron microscope-energy dispersive X-ray (SEM-EDX), and electron microprobe analysis (EMPA). Hydrothermal alteration at Cerro Quema appears mainly restricted to the dacite domes of the Río Quema Formation (Fig. 5) due to the difference in permeability and porosity with respect to other rock types of the volcanosedimentary sequence (Corral, 2013).

Hydrothermal alteration follows an easterly trend that is parallel to secondary faults of the Río Joaquín fault zone.
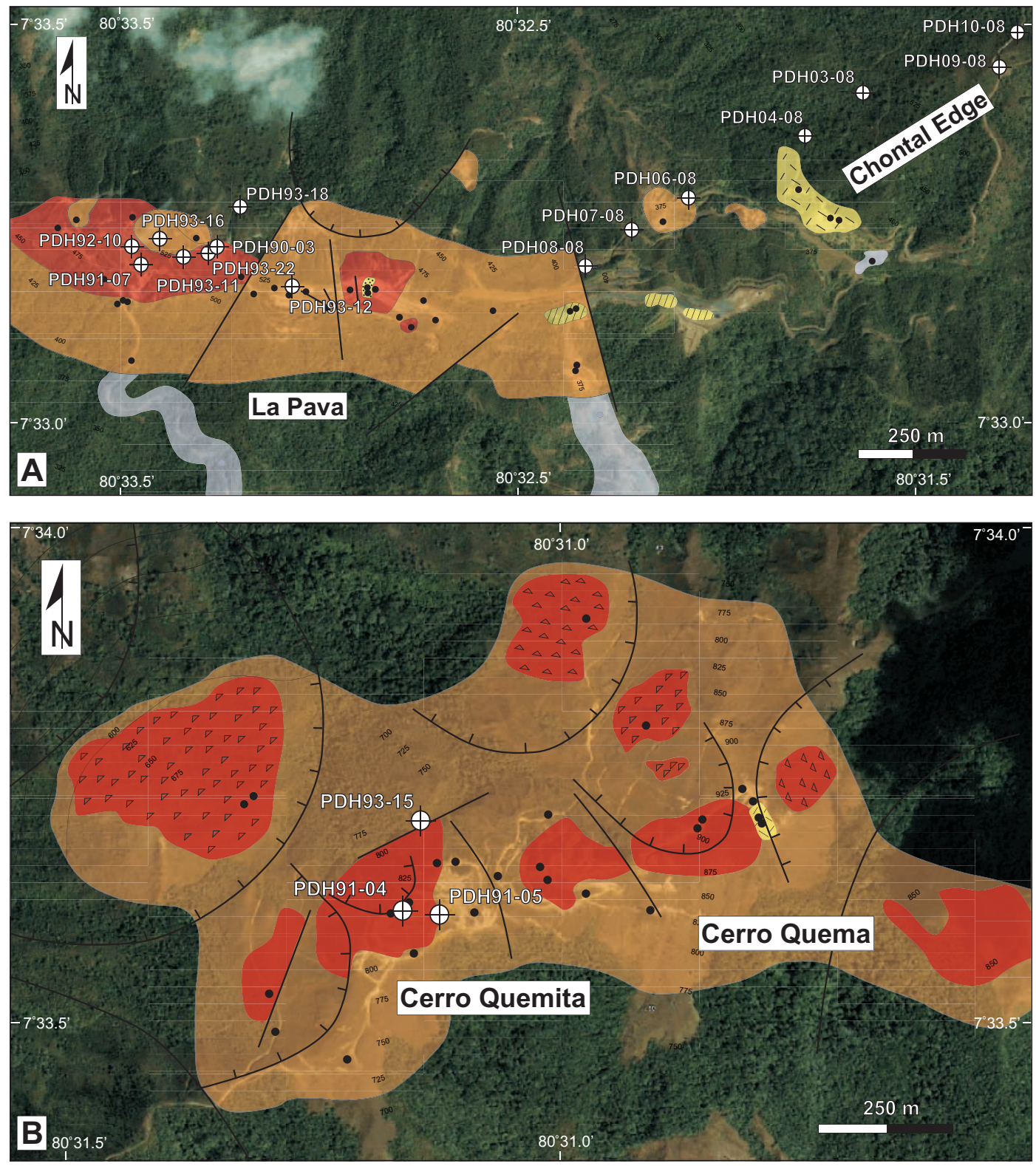

Vuggy quartz; quartz, barite, rutile and residual pyrite

Fresh rock; hydrothermally unaltered rock

Vuggy quartz fallen blocks; quartz, barite, rutile and residual pyrite

$\because$ Advanced argillic; quartz and alunite

Advanced argillic; quartz, kaolinite-dickite, pyrophyllite, barite, illite and pyrite

III Advanced argillic; quartz, kaolinite-dickite, barite,

IIV gypsum, illite and pyrite

Argillic; quartz, kaolinite, illite, illite-smectite, smectite and chlorite

Fig. 5. Cerro Quema hydrothermal alteration maps. A) La Pava orebody and Chontal Edge. B) Cerro Quemita and Cerro Quema orebodies (modified from Corral et al., 2011). Topographic map has been extracted from a 90-m Shuttle Radar Topography Mission (SRTM) digital elevation model (DEM). 
Volcaniclastic sedimentary rocks and andesite lava flows affected by the E-trending faults to the east and west of Cerro Quema have also been weakly affected by hydrothermal alteration. Dacites are easily distinguished, due to their characteristic porphyritic texture, even when hydrothermally altered (Figs. 5, 6A, 7A). Although hydrothermal alteration had a strong structural control, a lithological control is also evident in the mushroom-shaped alteration domains at shallow levels (e.g., La Pava).

The Cerro Quema alteration pattern consists of an inner zone of vuggy quartz (30-230 m wide), with local quartz-alunite and pyrophyllite (advanced argillic alteration, 30-200 m wide), enclosed by a kaolinite, illite, and illite/smectite-bearing widespread alteration zone (argillic alteration, $100-400 \mathrm{~m}$ wide; Fig. 5). Propylitic alteration has only been observed in some drill core samples, and forms a halo surrounding the argillic alteration zone.

\section{Vuggy quartz}

This innermost alteration zone (Fig. 5) occurs as irregular, generally vertical, funnel- and tabular-shaped bodies, and is commonly found on top of mineralized zones. Patches of massive quartz and silicified breccias are also present in this zone.

Vuggy quartz is made up of a groundmass of microcrystalline anhedral quartz grains, disseminated pyrite, barite, and minor rutile, with traces of sphalerite. At depth, vuggy quartz contains disseminated pyrite, chalcopyrite, enargite, and tennantite. Vuggy quartz texture is characterized by voids preserving the crystal morphology of hornblende and plagioclase (Figs. 6B, 7B). Drusy quartz, pyrite, and rutile have partially filled some void spaces. Quartz phenocrysts preserved within dacite contain secondary two-phase (liquid rich) fluid inclusions, possibly recording the fluids responsible for hydrothermal alteration and mineralization.

\section{Advanced argillic}

The advanced argillic alteration zone is an irregular halo developed around the vuggy quartz alteration zone (Fig. 5). The advanced argillic alteration zone has different mineralogical expressions depending on its occurrence (surface/ subsurface).

Quartz-alunite alteration associated with a massive quartzcemented breccia zone is exposed at surface at La Pava (Fig. $6 \mathrm{C})$. Alunite is a very fine grained minor component that is only identifiable by XRD and is associated with the breccia cement. A more representative association of the advanced argillic alteration at surface is characterized by quartz, dickite, pyrophyllite, barite, illite, and minor diaspore (at La Pava, Chontal Edge, and Cerro Quema). These minerals altered the massive and brecciated dacites (Fig. 6D) to quartz. Clay minerals (dickite, pyrophyllite, and illite) replaced hornblende and plagioclase, and also occur in the breccia as cement (Fig. 7C). Barite occurs along fractures and as part of breccia cement. Disseminated pyrite is characteristic of the advanced argillic alteration zone.

At depth, the advanced argillic alteration assemblage consists of quartz, alunite-natroalunite, aluminum phosphate-sulfate (APS) minerals, dickite, pyrophyllite, barite, and rutile. This assemblage has only been observed in drill core samples, associated with hydraulic breccias (Fig. 7D).

\section{Argillic}

The argillic alteration zone defines a halo surrounding the vuggy quartz and advanced argillic alteration zones (Fig. 5). The argillic envelope generally bounds the vuggy quartz zone with a sharp contact, whereas the contact with the advanced argillic zone is gradational. The whitish-gray, hydrothermally altered rock typically preserves the original volcanic textures (Fig. 6E). Argillic alteration produced quartz, kaolinite, illite, and illite-smectite with minor chlorite, which replaced hornblende and plagioclase crystals (Fig. 7E). Disseminated pyrite is found locally.

Minerals within the argillic alteration zone are zoned outward from the mineralized centers. Kaolinite is dominant proximal to ore, and the assemblage grades to kaolinite \pm illite, and then to \pm illite-smectite. Kaolinite \pm smectite \pm chloritesmectite and chlorite have been recognized in distal locations. At La Pava, there are subvertical pipe-like structures where dacites with hornblende and plagioclase phenocrysts have been replaced by quartz, dickite, barite, and pyrite alteration (advanced argillic alteration; Fig. 6F). These pipes have crosscut the argillic altered rocks (Fig. 6F).

\section{Propylitic}

A propylitic assemblage constitutes the most distal alteration halo, affecting dacites, andesites, and volcaniclastic sedimentary rocks (e.g., turbidites and debris flows; Fig. 6G). It is characterized by chlorite, epidote, carbonate, rutile, pyrite, and chalcopyrite, with minor hematite and magnetite. Hornblende has been partially to completely replaced by chlorite and epidote, and plagioclase by carbonate (Fig. 7F). Carbonates also occur as patches and veinlets. Minor amounts of pyrite, chalcopyrite, rutile, magnetite, and hematite have replaced hornblende, and also occur as disseminated grains. The propylitic zone has a transitional contact with the argillic alteration zone, where clay minerals have partially overprinted propylitic alteration minerals.

\section{Mineralization}

Gold occurs as disseminated submicroscopic grains and as invisible gold within pyrite (Corral et al., 2011a). Copper is associated with hypogene chalcopyrite, enargite, bornite and tennantite, and supergene covellite and chalcocite. Mineralization (gold and copper) is mainly associated with the vuggy quartz and advanced argillic alteration zones. However, minor gold and copper occurrences have been found in the argillic and propylitic alteration zones.

\section{Hypogene mineralization}

Hypogene mineralization is generally developed below the oxidized zone, even though small (meter scale) outcrops are found at surface. Pyrite is the most abundant sulfide at the Cerro Quema deposit; however, there is a group of accompanying sulfides also associated with the $\mathrm{Au}-\mathrm{Cu}$ mineralization.

Hypogene mineralization is divided into five stages (Fig. 8), where stages 3 and 4 are the main ore-forming stages. Stage 1 consists of disseminated, fine-grained, idiomorphic and subidiomorphic pyrite, accompanied by rutile and barite in voids and groundmass (Fig. 9A), with minor enargite, tennantite, and chalcopyrite at depth. Sphalerite is a trace mineral that 

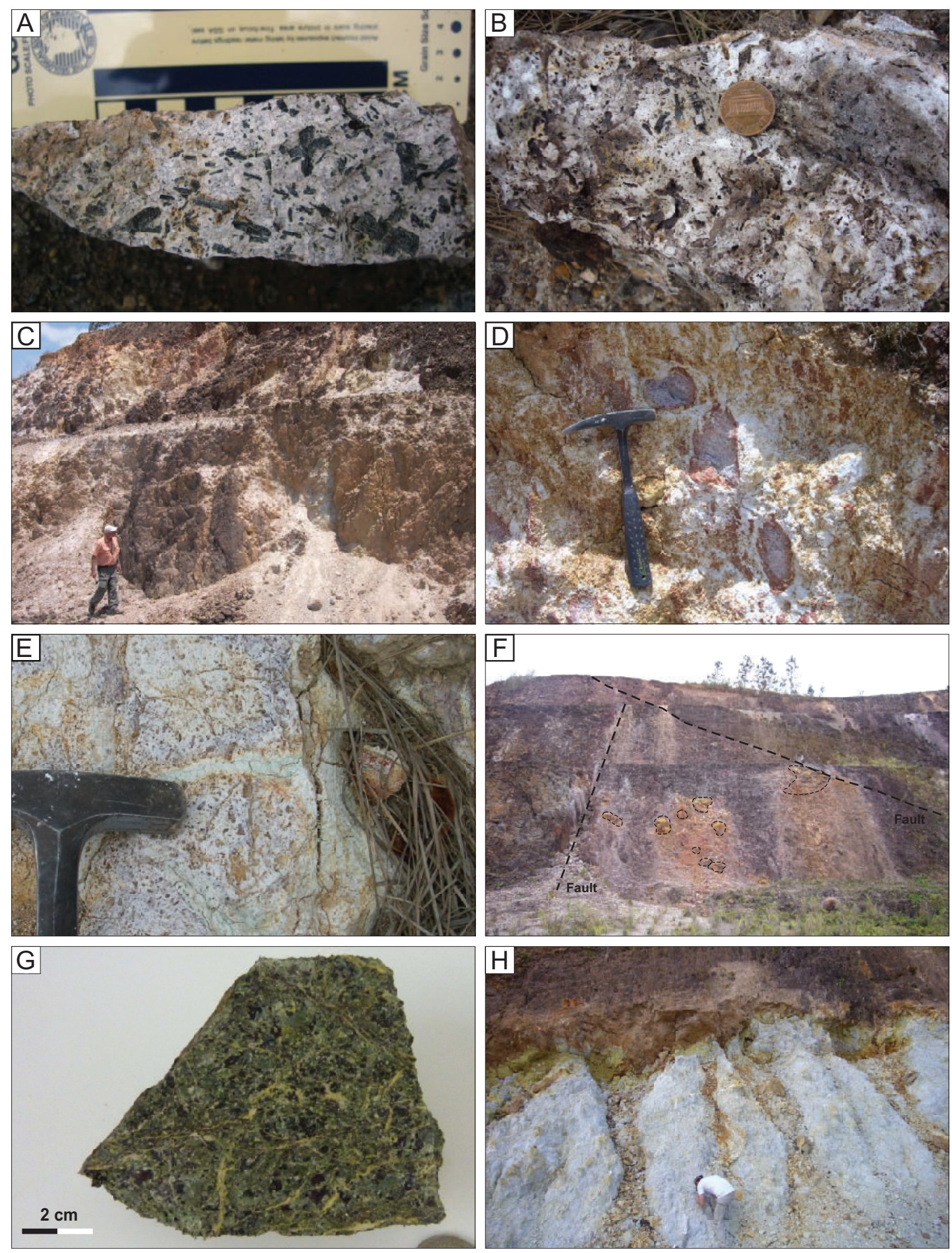

Fig. 6. Field examples of host rocks and hydrothermal alteration assemblages at Cerro Quema. A) Unaltered porphyritic texture of dacites (Río Quema Formation). B) Dacite altered to vuggy quartz at Cerro Quemita, preserving the original volcanic rock texture. Voids corresponding to hornblende and plagioclase crystals are now filled by Fe oxides. C) Quartzalunite-altered breccia zone at La Pava. D) Quartz-, dickite-, pyrophyllite-, barite-, and illite-altered breccia, composed by dacite clasts with argillic alteration in a matrix of advanced argillic alteration (Cerro Quema). E) Kaolinite-, illite-, and illite/ smectite-altered dacite preserving the original volcanic rock texture (Cerro Quemita). F) Pipe-like structures (dashed-line circles) composed of quartz, dickite, barite, and pyrite crosscutting the argillic alteration zone at La Pava. Image width $\sim 20 \mathrm{~m}$. G) Drill core sample showing a chlorite, epidote, pyrite, and carbonate alteration in a sedimentary breccia or microconglomerate, crosscut by carbonate veins. H) Oxidation boundary developed on the advanced argillic alteration zone at Chontal edge. 

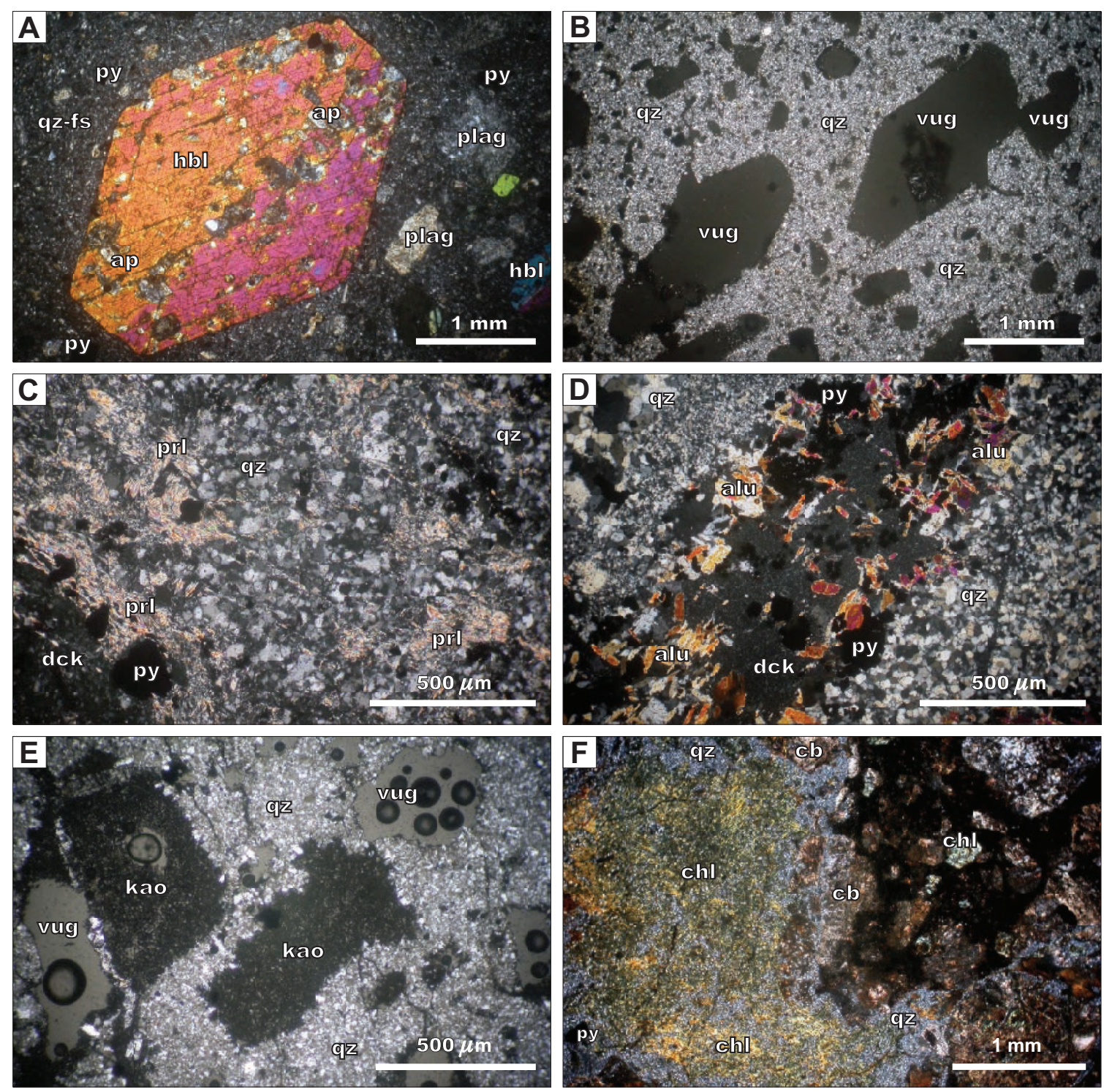

Fig. 7. Microscope images of alteration assemblages at Cerro Quema. A) Relatively fresh dacite showing honrnblende phenocrysts and partially calcite altered plagioclase crystals in a slightly altered groundmass (cross-polarized light). B) Vuggy quartz; dacite groundmass has been totally replaced by microcrystalline quartz, preserving the hornblende and plagioclase crystal morphologies (cross-polarized light). C) Dacite altered to quartz + dickite + pyrophyllite + pyrite assemblage, typical of the advanced argillic alteration assemblage (cross-polarized light). D) Hydraulic breccia with fragments of vuggy quartz cemented by alunite-natroalunite, pyrite, and dickite (cross-polarized light). E) Dacite affected by argillic alteration (crosspolarized light). Groundmass has been replaced by microcrystalline quartz and plagioclase voids have been filled by kaolinite. F) Cross-polarized light image of a sedimentary breccia affected by propylitic alteration. The matrix has been altered to quartz + chlorite + calcite + pyrite. Volcanic clasts have undergone selective replacement of plagioclase to calcite and hornblende to chlorite. Abbreviations: $\mathrm{ap}=$ apatite, alu $=$ alunite, $\mathrm{cb}=$ carbonate, $\mathrm{chl}=$ chlorite, $\mathrm{dck}=$ dickite, $\mathrm{hbl}=$ hornblende, kao = kaolinite, plag = plagioclase, $\mathrm{prl}=$ pyrophyllite, $\mathrm{py}=$ pyrite, $\mathrm{qz}=$ quartz, qz-fs = quartz-feldspar groundmass .

occurs disseminated in the groundmass. Stage 2 is constituted by disseminated pyrite in the cement of a hydraulic breccia, associated with alunite-natroalunite, dickite, and traces of chalcopyrite. Stage 3 consists of pyrite, chalcopyrite, enargite, and tennantite veinlets crosscutting stages 1 and 2 (Fig. 9B). Replacement textures of pyrite by enargite, enargite by tennantite, and tennantite by chalcopyrite are observed in the veinlets. Bornite occurs as a trace mineral. Stage 4 occurs as breccia bands $\sim 5 \mathrm{~cm}$ thick, composed of pyrite, chalcopyrite, and minor enargite. Breccia bands crosscut all the previous stages (Fig. 9C). Stage 5 reflects intermediate sulfidation mineralization. These 5- to 10 -cm-thick base metal sulfide-rich veins are composed of pyrite, quartz, and barite together with minor chalcopyrite, sphalerite, and galena (Fig. 9D).

\section{Supergene mineralization and alteration}

Intense weathering typical of tropical latitudes has affected fresh and hydrothermally altered rocks in the Cerro Quema area to depths of $150 \mathrm{~m}$. Sulfide oxidation in high sulfidation systems is largely controlled by rock permeability (Sillitoe, 


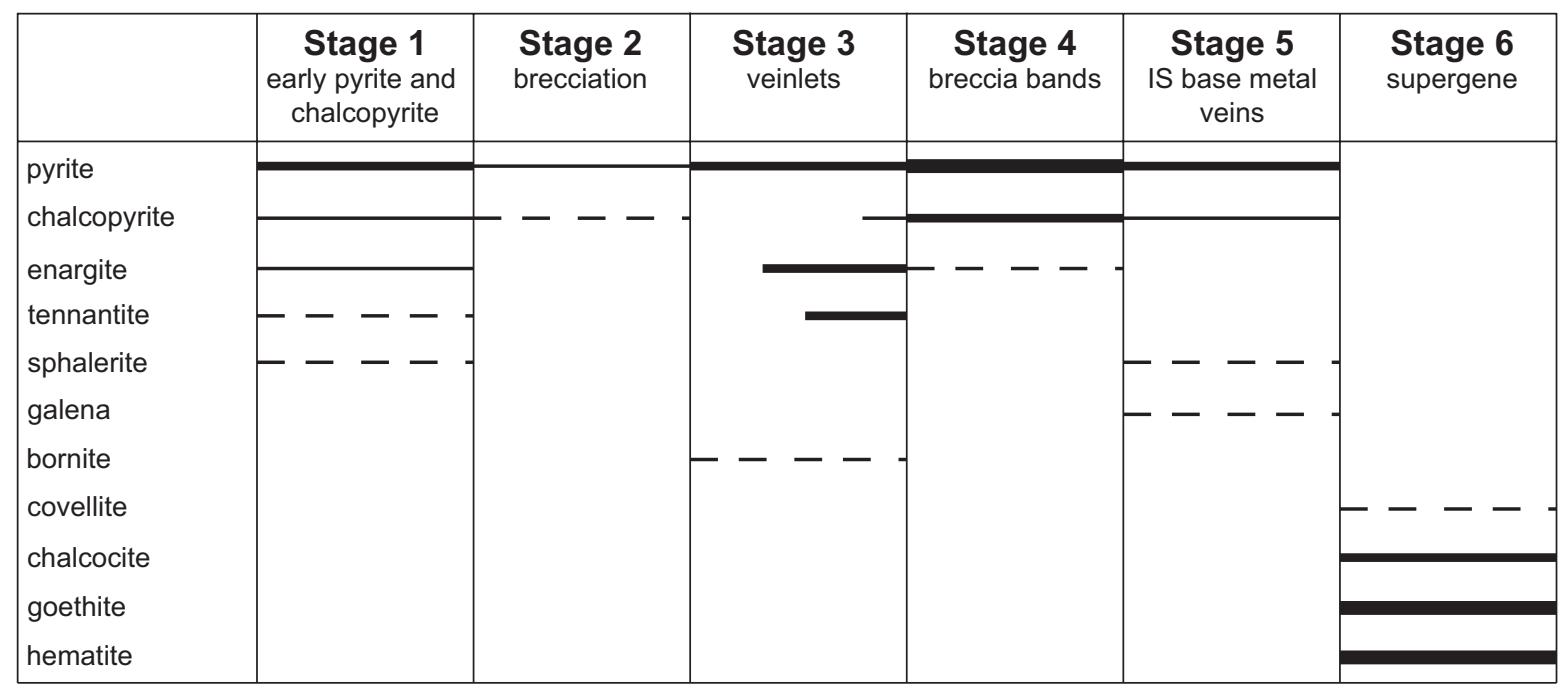

Fig. 8. Paragenetic sequence of ore minerals at Cerro Quema.

1999). At Cerro Quema, high permeability was provided by the vuggy quartz, hydrothermal breccias, fracture zones, and hyaloclastites (Fig. 6H).

Weathering of the high sulfidation ores has produced a thick quartz- and iron oxide-rich zone that overprinted the primary sulfide-bearing zone. This zone developed in the upper part of mineral bodies, and is characterized by vuggy quartz containing abundant hematite and goethite within the groundmass, replacing the cement of hydrothermal breccias, and filling voids in the vuggy quartz zone (Fig. 9E). Supergene jarosite, kaolinite, halloysite, and gypsum are also found in fractures, vugs, and breccia matrix. Hypogene pyrite, barite, and rutile remain as trace minerals in the oxidation zone.

Below the oxidation zone, supergene enrichment has caused deposition of secondary $\mathrm{Cu}$-bearing minerals such as chalcocite and minor covellite. The secondary $\mathrm{Cu}$ sulfides are found replacing chalcopyrite, tennantite, and enargite as well as filling small fractures (Fig. 9F).

The enrichment factor of the oxide zone with respect to the sulfide zone in terms of gold and copper is 2.41 and 0.61 , respectively (Corral, 2013). At Cerro Quema, the oxidation zone has higher gold grades (up to 2,400 ppb Au), and the enrichment zone has higher copper grades (up to $1 \% \mathrm{Cu}$ ).

\section{Trace Element Geochemistry}

Trace element data from high sulfidation epithermal deposits are not abundant (e.g., Nansatsu, Japan-Hedenquist et al., 1994; Rodalquilar, Spain-Hernandez et al., 1989; Pueblo Viejo, Dominican Republic-Kesler et al., 2003). Co/Ni and $\mathrm{S} / \mathrm{Se}$ ratios in pyrite have been used as empirical indicators of the depositional environment (e.g., Edwards and Carlos, 1954; Goldschmidt, 1954; Loftus-Hills and Solomon, 1967; Bralia et al., 1979). Pyrite compositions combined with major and trace element contents of alunite and APS group minerals may provide significant information for understanding their origin. Chemical composition of enargite, alunite, and APS minerals can be used as an ore guide in mineral exploration as they can be related in time and space to epithermal and porphyry mineralization (e.g., Bove, 1990; Dill, 2003; Chang et al., 2009, 2011; Deyell and Hedenquist, 2011).

Analyses of S, Fe, Co, Ni, Cu, As, Se, Ag, Cd, Sb, Au, and Hg have been performed by EMPA for 55 pyrites from six drill hole samples of the vuggy quartz and advanced argillic alteration. The contents of Al, Fe, Ca, Na, K, P, F, S, Cu, As, Sr, Ba, $\mathrm{Ce}$, and $\mathrm{Pb}$ of 20 alunites and 21 APS minerals were analyzed by EMPA from two drill core samples of the advanced argillic alteration. All the analyses were performed at the Serveis Científics i Tecnològics of the University of Barcelona.

\section{Pyrite}

Several pyrite types have been analyzed (e.g., idiomorphic, subidiomorphic, zoned, massive, framboidal, and brecciated; Fig. 10A, B). The aim was to determine the chemical composition of the different pyrite types. However, they have similar Ag, Cd, Sb, and Se concentrations, but some differences exist in Co and Ni concentrations (Table 1; Appendix 1). Co/ $\mathrm{Ni}$ ratios $(\mathrm{N}=11)$ range from 0.58 to 5.50 (Fig. 11A), and $\mathrm{S} /$ Se ratios $(\mathrm{N}=21)$ are between 1,050 and 2,694. Pyrites are generally $\mathrm{Cu}$ rich, varying from 0.03 to 3.67 wt $\% \mathrm{Cu}$. The $\mathrm{Au}, \mathrm{Hg}$, and As concentrations of pyrite are below detection limits.

\section{Alunite and APS minerals}

At Cerro Quema, alunite and APS minerals occur as cement in the hydraulic breccias associated with pyrite and dickite, filling voids in the vuggy quartz zone, and replacing plagioclase crystals (Fig. 10C, D). In general, alunite is zoned $(\sim 1-7 \mu \mathrm{m}$ wide), which is mainly due to the variation in $\mathrm{Na}, \mathrm{K}$, and $\mathrm{Ca}$ contents. Alunites have typical flaky shapes, indicating a hypogene origin (e.g., Arribas et al., 1995a; Itaya et al., 1996), and commonly have a core of APS minerals (e.g., svanbergite; Fig. 10C). Representative chemical data for alunite and APS minerals from Cerro Quema are shown in Table 2 and Appendix 2. Alunite is $\mathrm{Na}$ rich, exhibiting a compositional range within the alunite-natroalunite solid solution (Fig. 11B). P is generally present as a trace, excepting few alunite crystals that show $\mathrm{P}$ enrichment, which is also correlated with an enrichment in 

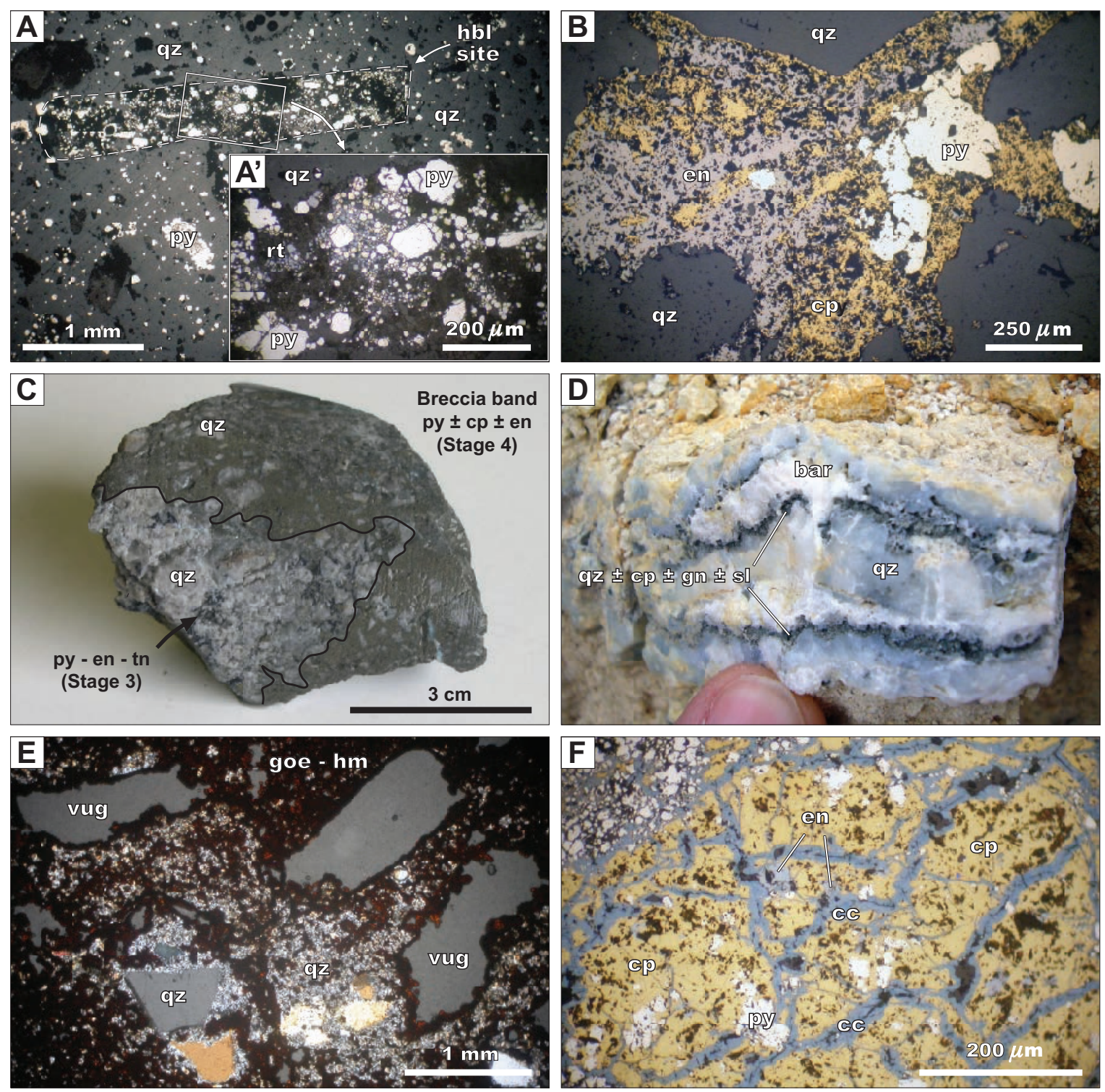

Fig. 9. Hypogene and supergene mineralization at Cerro Quema. A, A') Vuggy quartz with disseminated pyrite and replacement of hornblende by pyrite and rutile (reflected polarized light). B) Veinlets of pyrite + enargite + chalcopyrite crosscutting a vuggy quartz-altered dacite (reflected polarized light), corresponding to stage 3 . C) Breccia band composed of pyrite + chalcopyrite + enargite (stage 4) crosscutting veinlets of pyrite + enargite + tennantite (stage 3). D) Late-stage base metal veins composed of pyrite, quartz, and barite with traces of sphalerite and galena. E) Hematite-goethite botryoids in dacite altered by vuggy quartz. The original rock texture (porphyritic dacite) is still preserved (polarized light). F) Supergene enrichment zone of hypogene pyrite, chalcopyrite \pm enargite to chalcocite (reflected polarized light). Abbreviations: bar $=$ barite, $\mathrm{cc}=$ chalcocite, $\mathrm{cp}=$ chalcopyrite, $\mathrm{en}=$ enargite, $\mathrm{gn}$ = galena, goe = goethite, $\mathrm{hm}=$ hematite, $\mathrm{py}=$ pyrite, $\mathrm{qz}=$ quartz, $\mathrm{rt}=$ rutile, $\mathrm{sl}=$ sphalerite, $\mathrm{tn}=$ tennantite .

Sr and Ba. In contrast, APS minerals show irregular element content (e.g., $\mathrm{Na}, \mathrm{Ca}, \mathrm{Sr}, \mathrm{Ba}$, and $\mathrm{Fe}$ ), typically with enrichment in $\mathrm{Sr}$, and locally in $\mathrm{Ca}$ and $\mathrm{Ba}$ (Fig. 11C), which is characteristic of the svanbergite-woodhouseite solid solution.

\section{${ }^{40} \mathrm{Ar} /{ }^{39} \mathrm{Ar}$ Geochronology}

The first geochronological studies of arc rocks in the Azuero Peninsula were conducted by Del Giudice and Recchi (1969) and Kesler et al. (1977). Recent studies have focused on dating igneous rocks such as those at El Montuoso, Valle Rico, and Parita batholiths, as well as quartz-diorites from the Punta
Mala area, northeast Azuero basalts, and Central Azuero arc rocks (Fig. 1; Lissinna, 2005; Wegner et al., 2011; Montes et al., 2012). Results of the previous geochronological studies are summarized in Table 3.

$\mathrm{Ar} / \mathrm{Ar}$ step-heating dating has been conducted in this study in order to complete the existing radiometric and biostratigraphic ages of the volcanic, volcaniclastic, sedimentary, and plutonic rocks of the Azuero Peninsula, and to constrain the age of the Cerro Quema deposit. Mineral separates of eight hornblende phenocrysts were prepared by crushing $1 \mathrm{~kg}$ of rock, sieving, washing, and handpicking to obtain $100 \mathrm{mg}$ of 

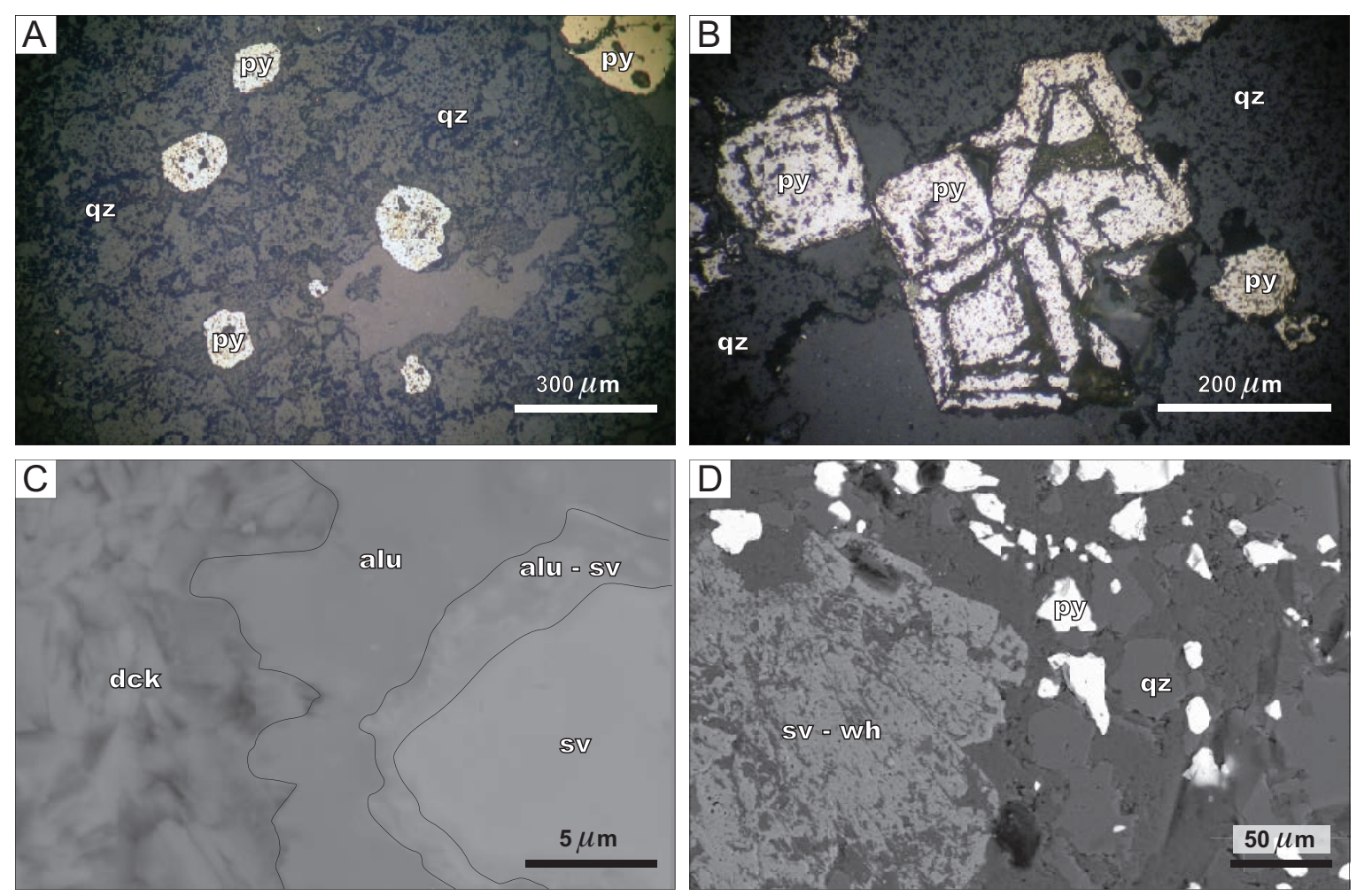

Fig. 10. Images of analyzed pyrite and alunite. A) Framboidal pyrite (reflected polarized light). B) Idiomorphic and zoned pyrite (reflected polarized light). C) Alunite crystal showing a core of svanbergite with an intermediate zone of intergrown alunite-svanbergite in a matrix of dickite (BSE image). D) Svanbertite-woodhouseite crystal in a quartz-pyritealtered matrix (BSE image). Abbreviations: alu = alunite, $\mathrm{dck}=$ dickite, $\mathrm{py}=$ pyrite, $\mathrm{qz}=$ quartz, $\mathrm{sv}=\mathrm{svanbergite}, \mathrm{sv}-\mathrm{wh}=$ svanbergite-woodhouseite.

optically pure mineral. The ${ }^{40} \mathrm{Ar} /{ }^{39} \mathrm{Ar}$ step-heating analyses were performed at the U.S. Geological Survey on samples irradiated at the U.S. Geological Survey TRIGA reactor in Denver, Colorado (Dalrymple et al., 1981). Dated samples are from the El Montuoso, Valle Rico, and Parita batholiths, the Cerro Quema host rock (dacite dome complex), and volcaniclastic andesite (Fig. 1). Results and sample locations are shown in Table 4 and in Figure 12.

\section{El Montuoso}

Two hornblendes from the El Montuoso batholith yielded ${ }^{40} \mathrm{Ar} /{ }^{39} \mathrm{Ar}$ plateau ages of $65.7 \pm 1.0$ and $67.5 \pm 1.1 \mathrm{Ma}$ (Fig. 12; Table 4), consistent with previous hornblende K/Ar ages $(69 \pm 10$ and $64.87 \pm 1.34 \mathrm{Ma}$; Del Giudice and Recchi, 1969; Kesler, 1977), and also with the zircon U/Pb ages $(67.7 \pm 1.4$, $66.0 \pm 1.0$, and $67.6 \pm 1.0 \mathrm{Ma}$ ) of Montes et al. (2012). Kesler (1977) also obtained a younger plagioclase K/Ar age (52.58 $\pm 0.63 \mathrm{Ma}$ ), interpreted to reflect partial postcrystallization argon loss from the plagioclase.

\section{Valle Rico}

${ }^{40} \mathrm{Ar} /{ }^{39} \mathrm{Ar}$ dating of a sample of the Valle Rico quartz-diorite (Fig. 12; Table 4) provided an integrated age of $54.8 \pm 1.2$ $\mathrm{Ma}$, which is consistent with the hornblende $\mathrm{K} / \mathrm{Ar}$ age of 53 $\pm 3 \mathrm{Ma}$ (Del Giudice and Recchi, 1969). However, our age is considerably older than plagioclase ${ }^{40} \mathrm{Ar} /{ }^{39} \mathrm{Ar}$ ages of 49.5 \pm 0.2 and $50.6 \pm 0.3 \mathrm{Ma}$ for the same batholith reported by Lissinna (2005). A recent zircon U/Pb age of $49.2 \pm 0.9 \mathrm{Ma}$
(Montes et al., 2012) suggests that this is the true age of this quartz diorite. The Valle Rico hornblende ${ }^{40} \mathrm{Ar} /{ }^{39} \mathrm{Ar}$ date is therefore interpreted to have been compromised by the presence of excess argon.

\section{Parita}

A hornblende from the Parita batholith yielded a small plateau-like segment at $40.9 \pm 1.3 \mathrm{Ma}$, in agreement with previous zircon $\mathrm{U} / \mathrm{Pb}$ ages of $48.1 \pm 1.2$ and $41.1 \pm 0.7 \mathrm{Ma}$ (Montes et al., 2012) of the Parita batholith. However, the ${ }^{40} \mathrm{Ar} /{ }^{39} \mathrm{Ar}$ spectra show evidence for excess argon (Fig. 12; Table 4).

\section{Río Quema Formation}

Four hornblendes separated from the dacite dome complex of the Río Quema Formation yielded ${ }^{40} \mathrm{Ar} /{ }^{39} \mathrm{Ar}$ plateau ages of $67.9 \pm 1.1,66.0 \pm 1.0$, and $65.6 \pm 1.3 \mathrm{Ma}$ and an integrated age of $69.7 \pm 1.2 \mathrm{Ma}$ (Fig. 12; Table 4). Wegner et al. (2011) reported hornblende ${ }^{40} \mathrm{Ar} /{ }^{39} \mathrm{Ar}$ ages of $71.0 \pm 2.0$ and $67.5 \pm$ $1.9 \mathrm{Ma}$ for two dacite samples found in the Tonosí River (central Azuero Peninsula), probably corresponding to boulders coming from the erosion of the dacite dome complex of the Río Quema Formation.

An attempt to date the volcaniclastic rocks of the Río Quema Formation was made. Unfortunately, the integrated age of $143 \pm 11 \mathrm{Ma}$ and the plateau age of $105 \pm 3 \mathrm{Ma}$ (Fig. 12: Table 4) have no geologic sense within the geologic framework of the Azuero Peninsula (the $143 \pm 11$ Ma age indicates that the rock is older than the Azuero igneous basement). 
Table 1. Quantitative Analyses and Co/Ni and S/Se Ratios of Pyrites from Cerro Quema

\begin{tabular}{|c|c|c|c|c|c|c|}
\hline Sample no. & $9107-11.55$ & $9343-66$ & 9316-173.2 & $9316-236$ & $0308-51.8$ & 0308-73.6 \\
\hline Alteration & Vuggy quartz & Vuggy quartz & Vuggy quartz & Vuggy quartz & Advanced argillic & Advanced argillic \\
\hline Location & La Pava & Cerro Idaida & La Pava & La Pava & Chontal Edge & Chontal Edge \\
\hline $\mathrm{Fe}($ wt $\%)$ & $\mathrm{n}=4$ & $\mathrm{n}=10$ & $\mathrm{n}=15$ & $\mathrm{n}=7$ & $\mathrm{n}=9$ & $\mathrm{n}=10$ \\
\hline Min-max & $43.68-46.63$ & $44.51-46.84$ & $44.10-46.72$ & $44.63-46.58$ & $44.61-46.51$ & $43.59-46.53$ \\
\hline Median & 44.68 & 45.38 & 45.76 & 45.44 & 45.97 & 46.17 \\
\hline Average $( \pm \mathrm{sd})$ & $44.92( \pm 1.48)$ & $45.61( \pm 0.72)$ & $45.61( \pm 0.69)$ & $45.37( \pm 0.66)$ & $45.72( \pm 0.64)$ & $45.87( \pm 0.85)$ \\
\hline $\mathrm{S}($ wt $\%)$ & $\mathrm{n}=4$ & $\mathrm{n}=10$ & $\mathrm{n}=15$ & $\mathrm{n}=7$ & $\mathrm{n}=9$ & $\mathrm{n}=10$ \\
\hline Min-max & $52.52-53.38$ & $53.10-53.85$ & $52.68-54.14$ & $52.85-53.54$ & $53.31-54.02$ & $53.08-54.06$ \\
\hline Median & 52.92 & 53.53 & 53.49 & 53.35 & 53.51 & 53.46 \\
\hline Average $( \pm \mathrm{sd})$ & $52.94( \pm 0.48)$ & $53.56( \pm 0.22)$ & $53.54( \pm 0.37)$ & $53.29( \pm 0.24)$ & $53.57( \pm 0.22)$ & $53.47( \pm 0.30)$ \\
\hline $\mathrm{Cu}($ wt $\%)$ & $\mathrm{n}=2$ & $\mathrm{n}=10$ & $\mathrm{n}=15$ & $\mathrm{n}=6$ & $\mathrm{n}=9$ & $\mathrm{n}=7$ \\
\hline Min-max & $1.12-1.14$ & $0.03-2.12$ & $0.06-3.67$ & $0.57-2.21$ & $0.05-1.72$ & $0.12-3.16$ \\
\hline Median & 1.13 & 0.47 & 0.24 & 1.28 & 0.24 & 0.19 \\
\hline Average $( \pm \mathrm{sd})$ & $1.13( \pm 0.01)$ & $0.82( \pm 0.74)$ & $0.56( \pm 0.94)$ & $1.22( \pm 0.61)$ & $0.48( \pm 0.57)$ & $0.71( \pm 1.11)$ \\
\hline Co (ppm) & $\mathrm{n}=3$ & $\mathrm{n}=0$ & $\mathrm{n}=2$ & $\mathrm{n}=4$ & $\mathrm{n}=3$ & $\mathrm{n}=1$ \\
\hline Min-max & $500-17,800$ & - & $183-800$ & $175-400$ & $200-300$ & 1,100 \\
\hline Median & 17,800 & - & 492 & 400 & 231.00 & - \\
\hline Average $( \pm \mathrm{sd})$ & $12,033( \pm 9,988)$ & - & $492( \pm 436)$ & $344( \pm 113)$ & $244( \pm 51)$ & - \\
\hline $\mathrm{Ni}(\mathrm{ppm})$ & $\mathrm{n}=3$ & $\mathrm{n}=1$ & $\mathrm{n}=2$ & $\mathrm{n}=4$ & $\mathrm{n}=1$ & $\mathrm{n}=1$ \\
\hline Min-max & $700-4,300$ & 300 & $200-700$ & $200-600$ & 300.00 & 200 \\
\hline Median & 4,300 & - & 450 & 400 & - & - \\
\hline Average $( \pm \mathrm{sd})$ & $3,100( \pm 2,078)$ & - & $450( \pm 354)$ & $400( \pm 183)$ & - & - \\
\hline Se (ppm) & $\mathrm{n}=4$ & $\mathrm{n}=1$ & $\mathrm{n}=5$ & $\mathrm{n}=4$ & $\mathrm{n}=4$ & $\mathrm{n}=3$ \\
\hline Min-max & $200-500$ & 300 & 200 & 200 & $200-300$ & $200-300$ \\
\hline Median & 400 & - & 200 & 200 & 200.00 & 200 \\
\hline Average $( \pm \mathrm{sd})$ & $375( \pm 150)$ & - & $200( \pm 0)$ & $200( \pm 0)$ & $225( \pm 50)$ & $233( \pm 58)$ \\
\hline $\mathrm{Ag}(\mathrm{ppm})$ & $\mathrm{n}=1$ & $\mathrm{n}=5$ & $\mathrm{n}=5$ & $\mathrm{n}=5$ & $\mathrm{n}=3$ & $\mathrm{n}=0$ \\
\hline Min-max & 400 & $300-300$ & 300 & $300-400$ & $300-400$ & - \\
\hline Median & - & 300 & 300 & 300 & 300 & - \\
\hline Average $( \pm \mathrm{sd})$ & - & $300( \pm 0)$ & $300( \pm 0)$ & $340( \pm 55)$ & $333( \pm 58)$ & - \\
\hline $\mathrm{Cd}(\mathrm{ppm})$ & $\mathrm{n}=4$ & $\mathrm{n}=2$ & $\mathrm{n}=1$ & $\mathrm{n}=0$ & $\mathrm{n}=2$ & $\mathrm{n}=1$ \\
\hline Min-max & $300-311$ & $300-300$ & 300 & - & 300 & 300 \\
\hline Median & 306 & 300 & - & - & 300 & - \\
\hline Average $( \pm \mathrm{sd})$ & $306( \pm 7.8)$ & $300( \pm 0)$ & - & - & $300( \pm 0)$ & - \\
\hline $\mathrm{Sb}(\mathrm{ppm})$ & $\mathrm{n}=1$ & $\mathrm{n}=1$ & $\mathrm{n}=7$ & $\mathrm{n}=2$ & $\mathrm{n}=4$ & $\mathrm{n}=5$ \\
\hline Min-max & 500 & 500 & $500-700$ & 500 & $500-700$ & $500-700$ \\
\hline Median & - & - & 600.00 & 500.00 & 600.00 & 600.00 \\
\hline Average $( \pm \mathrm{sd})$ & - & - & $600( \pm 100)$ & $500( \pm 0)$ & $600( \pm 82)$ & $600( \pm 71)$ \\
\hline $\mathrm{Co} / \mathrm{Ni}$ & $\mathrm{n}=3$ & $\mathrm{n}=0$ & $\mathrm{n}=2$ & $\mathrm{n}=4$ & $\mathrm{n}=1$ & $\mathrm{n}=1$ \\
\hline Min-max & $0.71-4.14$ & - & $0.92-1.14$ & $0.58-2.00$ & 1.00 & 5.50 \\
\hline Median & 4.14 & - & 1.03 & 0.73 & - & - \\
\hline Average $( \pm \mathrm{sd})$ & $3.00( \pm 4.81)$ & - & $1.03( \pm 0.16)$ & $1.01( \pm 0.66)$ & - & - \\
\hline $\mathrm{S} / \mathrm{Se}$ & $\mathrm{n}=4$ & $\mathrm{n}=1$ & $\mathrm{n}=5$ & $\mathrm{n}=4$ & $\mathrm{n}=4$ & $\mathrm{n}=3$ \\
\hline Min-max & $1,050-2,669$ & 1,782 & $2,634-2,694$ & $2,658-2,669$ & $1,801-2,681$ & $1,779-2,664$ \\
\hline Median & 1,414 & - & 2,675 & 2,665 & 2,678 & 2,654 \\
\hline Average $( \pm \mathrm{sd})$ & $1,637( \pm 769)$ & - & $2,671( \pm 25)$ & $2,664( \pm 5)$ & $2,459( \pm 439)$ & $2,365( \pm 508)$ \\
\hline
\end{tabular}

\section{Hydrothermal alteration and mineralization}

Geochronologic dating of the Cerro Quema hydrothermal alteration-mineralization was attempted by the performance of ${ }^{40} \mathrm{Ar} /{ }^{39} \mathrm{Ar}$ step-heating analysis on alunite (advanced argillic alteration). Unfortunately, we had no success due to the finegrained size of the alunite crystals and their intergrowths with kaolinite, which prevented the preparation of a pure alunite sample.

\section{Discussion}

\section{Deposit type}

Classification of Cerro Quema has been a matter of debate since the first studies were carried out in the area. T. M.
Leach (pers. comm., 1992) and Nelson (1995) considered the deposit to be a high sulfidation epithermal deposit potentially related to an underlying porphyry-style intrusion. In contrast, Nelson and Nietzen (2000) and Nelson (2007) proposed that Cerro Quema could be an oxidized $\mathrm{Au}-\mathrm{Cu}$ deposit transitional between epithermal deposits and volcanogenic massive sulfide deposits, similar to the Pueblo Viejo deposit, Dominican Republic.

The spatial distribution of hydrothermal alteration assemblage at Cerro Quema (e.g., vuggy quartz grading outward to advanced argillic, argillic, and propyllitic assembages) and the alteration mineralogy (e.g., alunite, APS minerals, barite, kaolinite, dickite, pyrophyllite), together with the mineralization style (e.g., dissemination and veinlets of pyrite, enargite, 
A
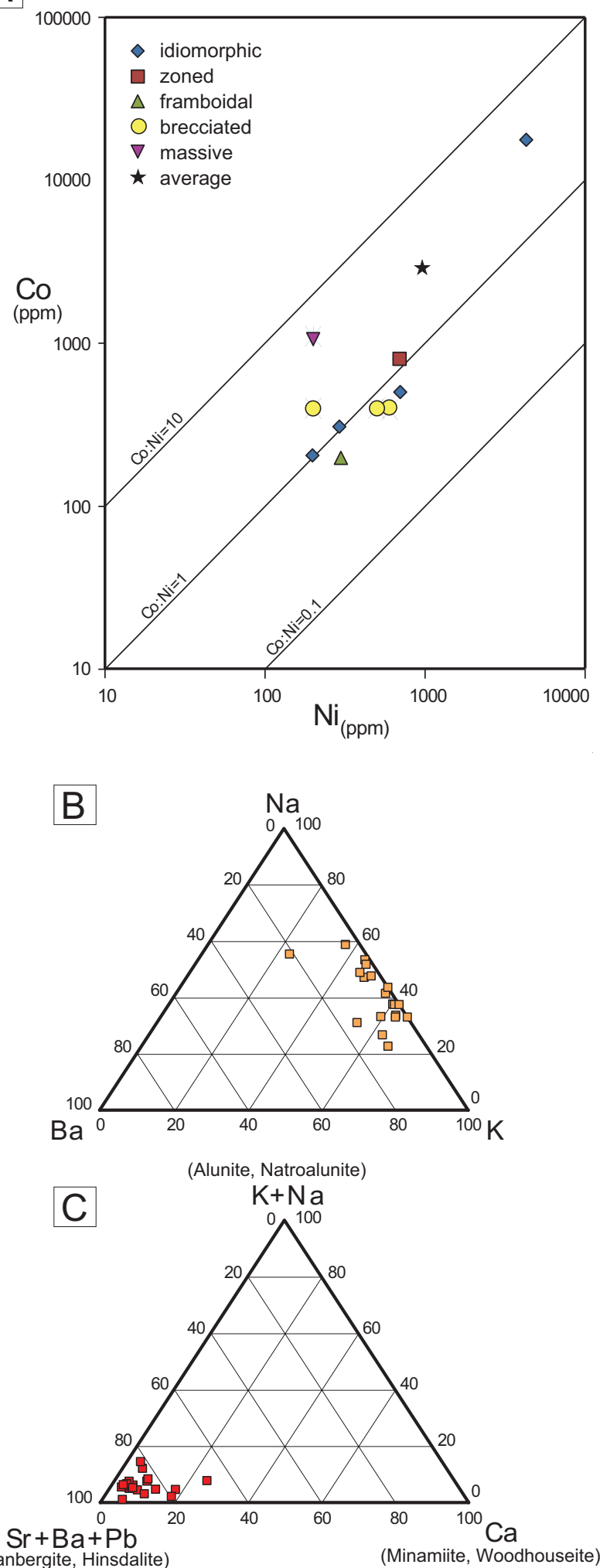

(Svanbergite, Hinsdalite)

(Minamiite, Woodhouseite)

Fig. 11. Chemical composition of pyrite, alunite, and APS minerals from Cerro Quema. A) Co-Ni content of pyrites and their average composition. B) Normalized K-Na-Ba compositions of alunite. Data points are recalculated EMPA compositions (20 analyses). C) Normalized K + Na-Sr + Ba + $\mathrm{Pb}-\mathrm{Ca}$ compositions of APS minerals. Data points are recalculated EMPA compositions (21 analyses).
Table 2. Representative Analyses of Alunites and APS Minerals from Cerro Quema

\begin{tabular}{lcccrr}
\hline \hline $\begin{array}{l}\text { Sample no. } \\
\text { Description }\end{array}$ & $\begin{array}{c}1 \\
\text { Natroalunite }\end{array}$ & $\begin{array}{c}2 \\
\text { Natroalunite }\end{array}$ & $\begin{array}{c}3 \\
\text { Natroalunite }\end{array}$ & \multicolumn{1}{c}{$\begin{array}{c}\text { APS } \\
\text { APS }\end{array}$} & \multicolumn{1}{c}{5} \\
\hline $\mathrm{Al}_{2} \mathrm{O}_{3}$ & 35.86 & 33.43 & 33.6 & 32.53 & 31.83 \\
$\mathrm{FeO}$ total & 0.05 & 0.14 & 2.16 & 0.00 & 0.26 \\
$\mathrm{CaO}$ & 0.02 & 0.17 & 0.23 & 0.77 & 2.49 \\
$\mathrm{Na} 2$ & 4.22 & 3.77 & 4.62 & 0.92 & 0.52 \\
$\mathrm{~K}_{2} \mathrm{O}$ & 4.31 & 3.56 & 1.98 & 0.52 & 0.41 \\
$\mathrm{P}_{2} \mathrm{O}_{5}$ & 0.25 & 2.42 & 3.20 & 12.33 & 17.53 \\
$\mathrm{~F}$ & 0.33 & 0.06 & 0.55 & 0.45 & 0.62 \\
$\mathrm{SO}_{3}$ & 38.43 & 35.85 & 34.34 & 20.14 & 16.65 \\
$\mathrm{CuO}^{\mathrm{As}} \mathrm{O}_{5}$ & 0.10 & 0.08 & 0.00 & 0.29 & 0.00 \\
$\mathrm{SrO}$ & 0.04 & 0.00 & 0.02 & 0.05 & 0.04 \\
$\mathrm{BaO}$ & 0.51 & 3.39 & 3.28 & 16.44 & 15.81 \\
$\mathrm{CeO}$ & 0.42 & 0.38 & 1.73 & 0.41 & 0.22 \\
$\mathrm{PbO}$ & 0.00 & 0.27 & 0.59 & 0.29 & 0.22 \\
$\left(\mathrm{H}_{2} \mathrm{O}\right)^{1}$ & 0.10 & 0.16 & 0.26 & 0.00 & 0.25 \\
$(\mathrm{Total})^{1}$ & 15.36 & 16.31 & 13.43 & 14.86 & 13.16 \\
& 100 & 100 & 100 & 100 & 100
\end{tabular}

\begin{tabular}{lrrrrr}
$\mathrm{Al}$ & 2.83 & 2.65 & 2.78 & 2.81 & 2.80 \\
$\mathrm{Fe}$ & 0.00 & 0.01 & 0.13 & 0.00 & 0.02 \\
$\mathrm{Ca}$ & 0.00 & 0.01 & 0.02 & 0.06 & 0.20 \\
$\mathrm{Na}$ & 0.55 & 0.49 & 0.63 & 0.13 & 0.08 \\
$\mathrm{~K}$ & 0.37 & 0.31 & 0.18 & 0.05 & 0.04 \\
$\mathrm{P}$ & 0.01 & 0.14 & 0.19 & 0.77 & 1.11 \\
$\mathrm{~F}$ & 0.07 & 0.01 & 0.12 & 0.10 & 0.15 \\
$\mathrm{~S}$ & 1.93 & 1.81 & 1.81 & 1.11 & 0.93 \\
$\mathrm{Cu}$ & 0.01 & 0.00 & 0.00 & 0.02 & 0.00 \\
$\mathrm{As}$ & 0.00 & 0.00 & 0.00 & 0.00 & 0.00 \\
$\mathrm{Sr}$ & 0.02 & 0.13 & 0.13 & 0.70 & 0.68 \\
$\mathrm{Ba}$ & 0.01 & 0.01 & 0.05 & 0.01 & 0.01 \\
$\mathrm{Ce}$ & 0.00 & 0.01 & 0.02 & 0.01 & 0.01 \\
$\mathrm{~Pb}$ & 0.00 & 0.00 & 0.00 & 0.00 & 0.01 \\
$\mathrm{Calculated} \mathrm{H}$ & 6.86 & 7.32 & 6.30 & 7.28 & 6.54 \\
Total cations & 12.66 & 12.91 & 12.36 & 13.05 & 12.55 \\
& & & & & \\
\hline
\end{tabular}

Oxide content is expressed in wt \%; 1 = Na-rich alunite (natroalunite), $2=$ Sr-rich natroalunite, $3=\mathrm{Sr}-, \mathrm{P}-$, and Ba-rich natrolaunite (natroalunitesvanbergite), $4=$ Sr-rich APS (svanbergite), $5=$ Sr- and Ca-rich APS (svanbergite-woodhouseite)

${ }^{1}$ Calculated by difference

${ }^{2}$ Assume $100 \%$ sum

tennantite, chalcopyrite), show that Cerro Quema fits well within the classical high sulfidation epithermal model (e.g., Hedenquist, 1987; Berger and Henley, 1989; White, 1991; Hedenquist and Lowenstern, 1994; Arribas et al., 1995a). Therefore, it can be also considered as a mineralized lithocap, possibly overlying a porphyry copper system, in the sense of Sillitoe (1995) and Corbett and Leach (1998). Consequently, in agreement with T. M. Leach (pers. comm., 1992), hydrothermal alteration and high sulfidation epithermal mineralization at Cerro Quema is inferred to be related to the circulation of acidic fluids derived from an underlying porphyry-like intrusion.

\section{Pyrite origin}

No relationships between trace element content and pyrite textures (idiomorphic, zoned, or framboidal; Fig. 10) were observed. Pyrites do not show significant differences in terms of major and trace elements, except for their $\mathrm{Cu}, \mathrm{Co}$, and $\mathrm{Ni}$ content (Table 1). Co/Ni ratios in pyrites have been 
Table 3. Summary of Geochronological Studies Carried Out in the Azuero Peninsula

\begin{tabular}{|c|c|c|c|c|c|c|c|c|c|}
\hline & \multirow{2}{*}{$\begin{array}{l}\text { Dating } \\
\text { method }\end{array}$} & \multirow[b]{2}{*}{ Rock } & \multirow[b]{2}{*}{ Mineral } & \multicolumn{6}{|c|}{ Results } \\
\hline & & & & El Montuoso & Valle Rico & Punta Mala & NE Azuero & Dacite & Parita \\
\hline \multirow[t]{2}{*}{$\begin{array}{l}\text { Del Giudice } \\
\text { and Recchi (1969) }\end{array}$} & $\mathrm{K} / \mathrm{Ar}$ & Qd & Hornblende & $69 \pm 10 \mathrm{Ma}$ & & & & & \\
\hline & & Qd & Hornblende & & $53 \pm 3 \mathrm{Ma}$ & & & & \\
\hline \multirow[t]{2}{*}{ Kesler et al. (1977) } & $\mathrm{K} / \mathrm{Ar}$ & Qd & Hornblende & $64.87 \pm 1.34 \mathrm{Ma}$ & & & & & \\
\hline & & Qd & Feldspar & & $52.58 \pm 0.63 \mathrm{Ma}$ & & & & \\
\hline \multirow[t]{5}{*}{ Lissinna (2005) } & $\mathrm{Ar} / \mathrm{Ar}$ & Gd & Plagioclase & & $49.5 \pm 0.2 \mathrm{Ma}$ & & & & \\
\hline & & Gr & Plagioclase & & $50.6 \pm 0.3 \mathrm{Ma}$ & & & & \\
\hline & & $\mathrm{B}$ & Matrix & & & $52.0 \pm 0.2 \mathrm{Ma}$ & & & \\
\hline & & $\mathrm{Gr}$ & Plagioclase & & & $50.7 \pm 0.1 \mathrm{Ma}$ & & & \\
\hline & & $\mathrm{B}$ & Matrix & & & & $60.9 \pm 0.5 \mathrm{Ma}$ & & \\
\hline \multirow{2}{*}{ Wegner et al. (2011) } & $\mathrm{Ar} / \mathrm{Ar}$ & Dac & Hornblende & & & & & $67.5 \pm 1.9 \mathrm{Ma}$ & \\
\hline & & $\mathrm{Dac}$ & Hornblende & & & & & $71.0 \pm 2.0 \mathrm{Ma}$ & \\
\hline \multirow[t]{6}{*}{ Montes et al. (2012) } & $\mathrm{U} / \mathrm{Pb}$ & Gd & Zircon & $67.6 \pm 1.4 \mathrm{Ma}$ & & & & & \\
\hline & & Ton & Zircon & $66.0 \pm 1.0 \mathrm{Ma}$ & & & & & \\
\hline & & Ton & Zircon & $67.6 \pm 1.0 \mathrm{Ma}$ & & & & & \\
\hline & & Ton & Zircon & & $49.2 \pm 0.9 \mathrm{Ma}$ & & & & \\
\hline & & Ton & Zircon & & & & & & $41.1 \pm 0.7 \mathrm{Ma}$ \\
\hline & & Ton & Zircon & & & & & & $48.1 \pm 1.2 \mathrm{Ma}$ \\
\hline
\end{tabular}

Abbreviations: $\mathrm{B}$ = basalt, $\mathrm{Dac}=$ dacite, $\mathrm{Gd}$ = granodiorite, $\mathrm{Gr}=$ granite, $\mathrm{Qd}=$ quartz diorite, Ton = tonalite

used to distinguish between magmatic-hydrothermal and sedimentary origin. Ratios from $\sim 1$ to 5 have usually been assigned to hydrothermal pyrites, whereas $\mathrm{Co} / \mathrm{Ni}$ ratio values of $<1$ are typical of pyrites of sedimentary or digenetic origin (e.g., Loftus-Hills and Solomon, 1967; Price, 1972; Bralia et al., 1979; Bajwah et al., 1987; Brill, 1989; Raymond, 1996; Fintor et al., 2011). Cerro Quema pyrites have $\mathrm{Co} / \mathrm{Ni}$ ratios ranging from 0.58 to 5.50 (Fig. 11A), with an average of 1.96, suggesting a hydrothermal origin, irrespective of their textures.

$\mathrm{S} / \mathrm{Se}$ ratios have also been used to discriminate between sedimentary and magmatic-hydrothermal origins of pyrites (e.g., Edwards and Carlos, 1954; Hawley and Nichol, 1959;
Huston et al., 1995; Fitzpatrick, 2008). S/Se values of $<15,000$ correspond to magmatic-hydrothermal origin whereas those of sedimentary origin have values larger than 30,000 . S/Se ratio values of pyrites from Cerro Quema range from 1,050 to 2,694 , pointing to a magmatic-hydrothermal origin.

All these results are in agreement with pyrite sulfur isotopes ( -4.8 to $-12.7 \%$ ) and bulk sulfur isotope composition $(-0.5 \%)$, suggesting a sulfide-dominant hydrothermal fluid of magmatic origin (Corral et al., 2011b; Corral, 2013).

\section{Alunite and APS origin}

Analyzed alunite crystals have a flaky shape and are $\mathrm{Na}$ rich, covering a wide range of the alunite-natroalunite solid

Table 4. Summary of ${ }^{39} \mathrm{Ar} / 40 \mathrm{Ar}$ Incremental-Heating Experiments

\begin{tabular}{|c|c|c|c|c|c|c|}
\hline \multirow[b]{2}{*}{ Sample no. } & \multicolumn{2}{|c|}{ Coordinates $\left({ }^{\circ} \mathrm{WGS} 84\right)$} & \multirow[b]{2}{*}{ Rock } & \multirow[b]{2}{*}{ Mineral } & \multirow{2}{*}{$\frac{\text { Plateau }}{\text { Age }(\mathrm{Ma}) \pm \sigma}$} & \multirow[b]{2}{*}{$\mathrm{N}$} \\
\hline & Latitude & Longitude & & & & \\
\hline \multicolumn{7}{|c|}{ El Montuoso batholith } \\
\hline PIT 01 & 7.643911 & -80.646462 & $\begin{array}{l}\text { Quartz-diorite } \\
\text { Quartz-diorite }\end{array}$ & $\begin{array}{l}\text { Amphibole } \\
\text { Amphibole }\end{array}$ & $\begin{array}{l}65.7 \pm 1.4 \\
65.5 \pm 0.7^{1}\end{array}$ & $\begin{array}{l}4 \text { of } 8 \\
9 \text { of } 9\end{array}$ \\
\hline \multicolumn{7}{|c|}{ Dacite (Río Quema Fm) } \\
\hline LP 204 & 7.544964 & -80.542382 & $\begin{array}{l}\text { Dacite } \\
\text { Dacite } \\
\text { Dacite } \\
\text { Dacite }\end{array}$ & $\begin{array}{l}\text { Amphibole } \\
\text { Amphibole } \\
\text { Amphibole } \\
\text { Amphibole }\end{array}$ & $\begin{array}{l}67.9 \pm 1.3 \\
69.7 \pm 1.2^{1} \\
66.0 \pm 1.1 \\
65.6 \pm 1.3\end{array}$ & $\begin{array}{l}5 \text { of } 9 \\
7 \text { of } 7 \\
5 \text { of } 7 \\
3 \text { of } 6\end{array}$ \\
\hline \multicolumn{7}{|c|}{ Volcaniclastic rocks (Río Quema Fm) } \\
\hline LP 111 & 7.532564 & -80.552439 & $\begin{array}{l}\text { Volcaniclastic andesite } \\
\text { Volcaniclastic andesite }\end{array}$ & $\begin{array}{l}\text { Amphibole } \\
\text { Amphibole }\end{array}$ & $\begin{array}{l}143 \pm 11^{1} \\
105 \pm 3\end{array}$ & $\begin{array}{r}10 \text { of } 10 \\
4 \text { of } 13\end{array}$ \\
\hline \multicolumn{7}{|c|}{$\underline{\text { Valle Rico batholith }}$} \\
\hline TRI 01 & 7.620795 & -80.300616 & Quartz-diorite & Amphibole & $54.8 \pm 1.2^{1}$ & 11 of 11 \\
\hline$\frac{\text { Parita bathol }}{\text { PA } 01}$ & 7.994204 & -80.527150 & Diorite & Amphibole & $40.8 \pm 1.4$ & 4 of 12 \\
\hline
\end{tabular}

${ }^{1}$ Integrated age 

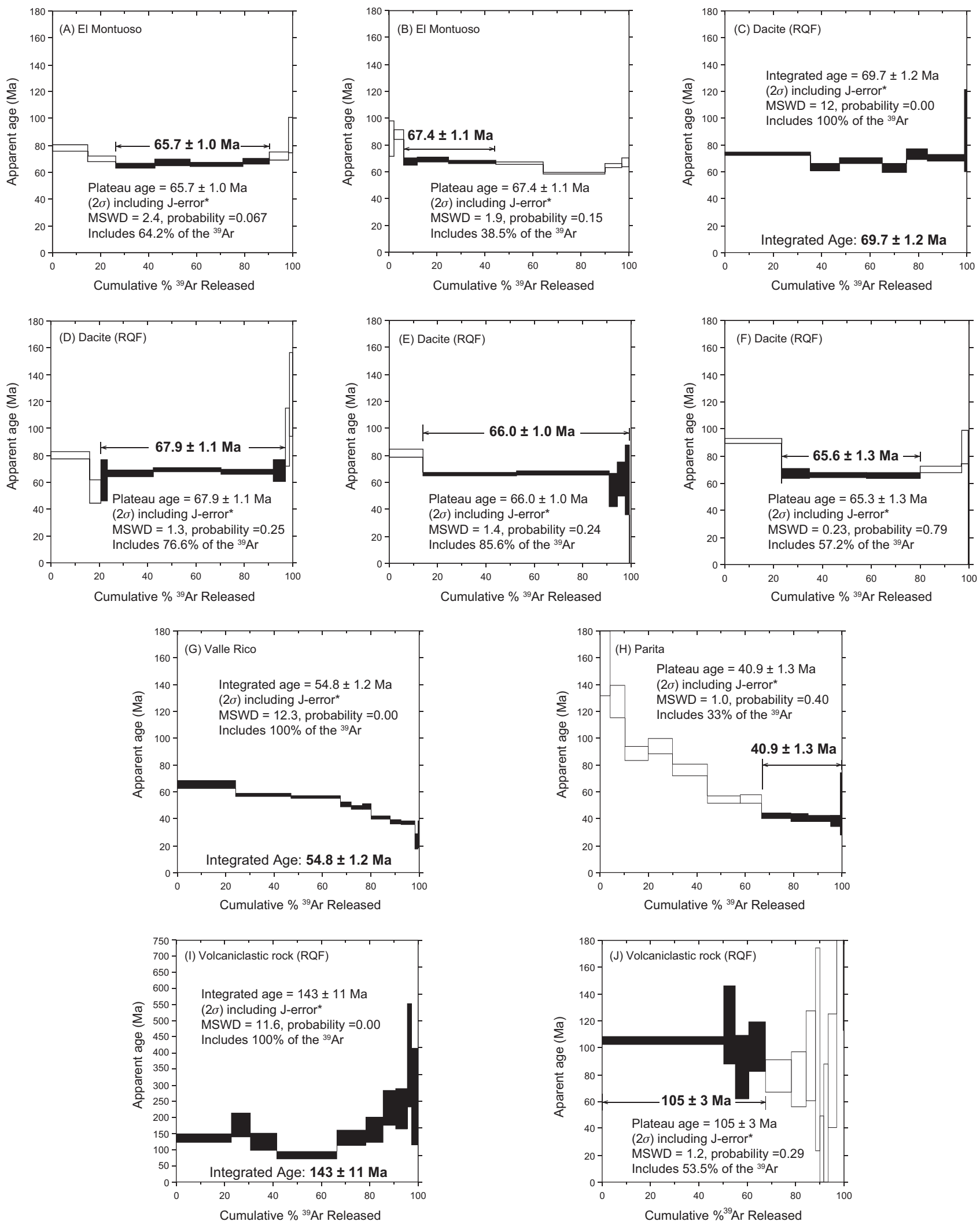

*J $\pm 1 \sigma=0.004349 \pm 0.002$

Fig. 12. Hornblende argon age spectra of rocks from Cerro Quema. Arrows indicate the steps used for plateau age calculation. A, B) El Montuoso batholith, C-F) Dacite dome complex (Río Quema Formation), G) Valle Rico batholith, H) Parita batholith, I, J) Volcaniclastic sediments of the Río Quema Formation. 
solution (Fig. 11B; Table 2; Appendix 2). APS minerals in the core of alunite and occurring as single crystals are mainly $\mathrm{Sr}$ rich, locally showing Ca enrichment (Fig. 11C; Table 2; Appendix 2), characteristic of the svanbergite-woodhouseite solid solution.

Studies focused on the alunite geochemistry (e.g., Stoffregen and Alpers, 1987; Arribas et al., 1995b; Deyell et al., 2005a, b; Chang et al., 2011) showed that supergene alunite and low-temperature alunite are generally $\mathrm{K}$ rich in comparison with higher-temperature occurrences, which are Na rich. Aoki et al. (1993) suggested that the core of hypogene alunite is commonly enriched in $\mathrm{PO}_{4}$ and multivalent cations such as $\mathrm{Ca}$ (crandalite, woodhouseite), $\mathrm{Sr}$ (svanbergite), and $\mathrm{Ba}$ (groceixite). These inclusions are typically rimmed by minamiite and rhythmic bands of alunite and natroalunite (Stoffregen and Alpers, 1987; Aoki et al., 1993). According to the aforementioned studies, texture and chemical composition of alunite (Na-rich, flaky shapes and with inner core of APS) and svanbergite-woodhouseite ( $\mathrm{Sr}$ - and Ca-rich APS mineral, occurring as an alunite core as well as single crystals) from Cerro Quema (see Figs. 10, 11; Table 2) present all of the characteristics indicating a magmatic-hydrothermal origin related to an intrusion-driven hydrothermal system, such as a porphyry copper intrusion.

\section{Geologic Evolution and Epithermal Mineralization}

This section summarizes the events from Late Cretaceous to present times that constrained the geologic evolution of the Azuero Peninsula and the formation of Cerro Quema (Fig. 13).

\section{Arc development}

The late Campanian ( 75-73 Ma) marked the initiation of Farallon plate subduction beneath the Caribbean plate (Buchs et al., 2010). The initial stages of an intraoceanic subduction are characterized by extension of the overriding plate (Stern and Bloomer, 1992; Stern, 2010). In the Azuero Peninsula, this extension controlled the morphology and evolution of the volcanic arc and fore arc. From late Campanian to Maastrichtian ( 71-66 Ma), the first stage of magmatism occurred within the Caribbean plate. This stage is characterized by the intrusion of El Montuoso batholith and the development of the arc and fore-arc basin. The Río Quema Formation, of late Campanian to Maastrichtian age, represents the fore-arc basin. Contemporaneous intrusions of dacite domes ( 71-66 Ma) into the Río Quema Formation resulted in the interstratified volcanic and sedimentary sequences of the fore-arc basin (Fig. 13A).

\section{Arc maturation and emplacement of the Cerro Quema deposit}

During the lower Eocene ( 55-49 Ma), a second stage of magmatism occurred (Fig. 13B), where the Paleogene volcanic arc developed on top of the Cretaceous volcanic arc. Valle Rico-like batholiths intruded along E-trending regional faults to the north of the Cretaceous fore-arc basin. However, some Valle Rico-like intrusions (quartz-diorites, diorites, and trachyandesites) also occurred in the central and southern limit of the fore-arc basin. Emplacement of Valle Rico intrusions in the fore-arc led to the formation of Cerro Quema.

\section{Age of the Cerro Quema deposit}

The age of Cerro Quema has been constrained from field evidence coupled with biostratigraphic data of sedimentary rocks of the Río Quema Formation and geochronological data of the igneous rocks of the Azuero Peninsula. The age of the deposit is estimated to be $\sim 55$ to $49 \mathrm{Ma}$ (lower Eocene), based on the following observations:

1. Crystal-rich sandstones and turbidites of the Río Quema Formation, a volcanosedimentary sequence of CampanianMaastrichtian age, do not contain altered clasts derived from hydrothermally altered rocks. Dacite clasts in conglomerates derived from the erosion of the dacite dome complex that hosts Cerro Quema ( 71-66 Ma; Wegner et al., 2011) show no signs of hydrothermal alteration. Therefore, hydrothermal alteration and mineralization should be younger than the age of the dacite dome complex ( 71-66 $\mathrm{Ma}$.

2. As a high sulfidation deposit, Cerro Quema will have been related to a magmatic event. In the Azuero Peninsula, the first recorded post-Cretaceous magmatic event occurred during the lower Eocene ( 55-49 Ma; Del Giudice and Recchi, 1969; Kesler et al., 1977; Lissinna, 2005; Montes et al., 2012), corresponding to Valle Rico-like batholith intrusions. Based on correlations with this second magmatic event, the maximum age of Cerro Quema is lower Eocene (55-49 Ma).

\section{Arc migration}

During the middle Eocene ( $45 \mathrm{Ma}$ ), the Azuero Peninsula was an area of accreted intraoceanic island arcs, such as la Hoya and Punta Blanca islands (Buchs et al., 2011b). Subduction erosion and possible slab flattening induced the migration of the arc front toward the Caribbean. The emplacement of the Parita batholith ( 48-41 Ma) to the north of the OcúParita fault (Fig. 1) supports arc migration toward the north during middle Eocene times. This migration is in agreement with geodynamic reconstructions of Buchs et al. (2010) and geochronological data of Lissinna et al. (2002).

In the Azuero Peninsula, volcanism was less intense in the Cerro Quema and Tonosí area due to arc migration (Fig. 1). It allowed development of an overlapping sedimentary sequence (e.g., Tonosí Formation). This unit overlaps all older units, and is composed of reefal limestones, calcarenites, sandstones, conglomerates, and coal seams (Recchi and Miranda, 1977; Krawinkel and Seyfried, 1994; Kolarsky et al., 1995; Krawinkel et al., 1999).

\section{Erosion and supergene enrichment}

Some time before the emplacement of the Cerro Quema deposit ( $55-49 \mathrm{Ma}$ ) and present day, erosion and supergene enrichment affected the Cerro Quema deposit (Fig. 13C). Consequently, oxidation and intense weathering generated a thick Au-bearing, silica- and iron-rich zone of up to $150-\mathrm{m}$ depth, below which a Cu-rich zone was developed.

\section{Conclusions}

Cerro Quema is a high sulfidation epithermal deposit hosted by the dacite dome complex of the Río Quema Formation, and was emplaced into a Cretaceous fore-arc sequence. 


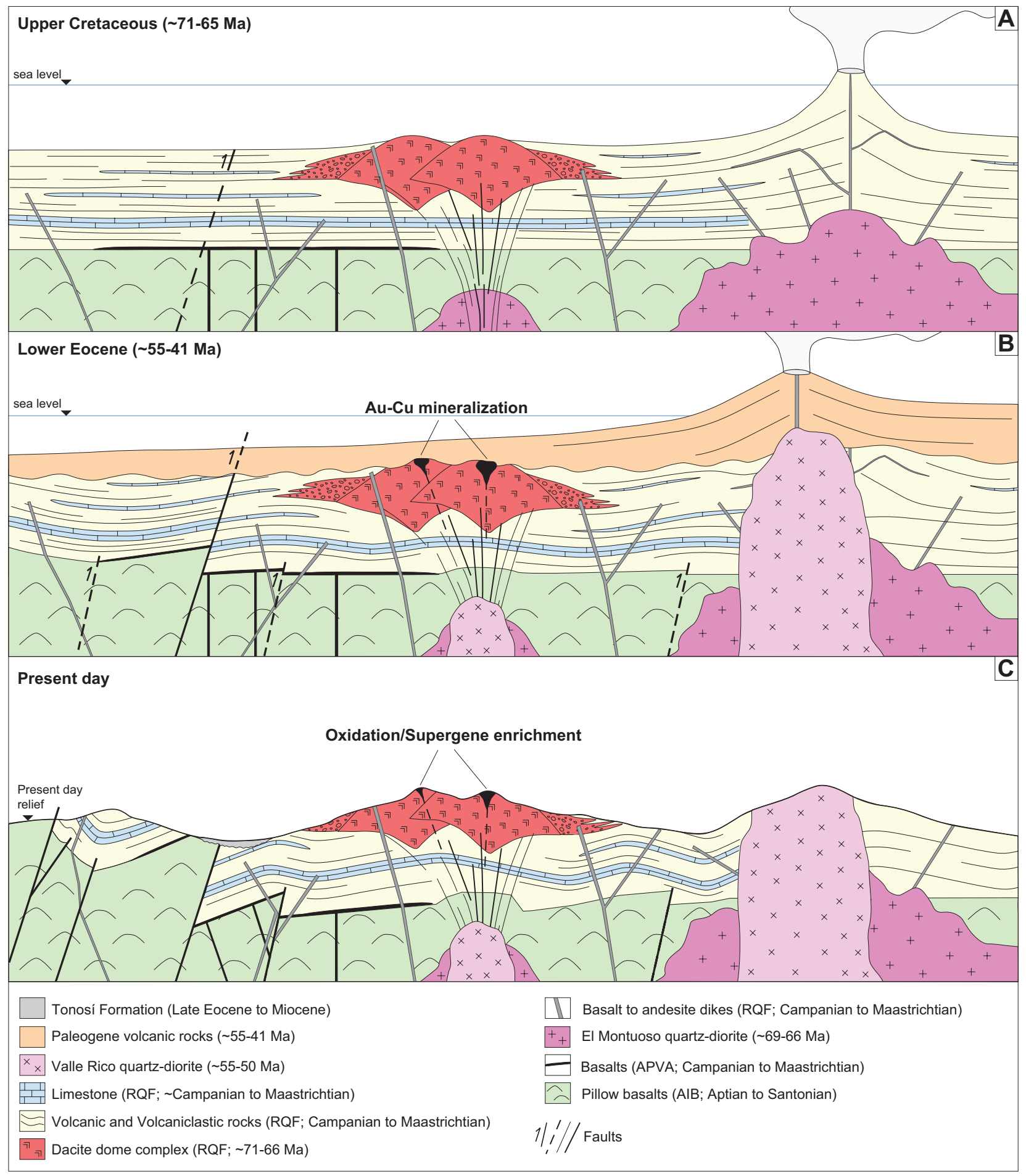

Fig. 13. Geologic model of Cerro Quema and the Azuero Peninsula from Late Cretaceous to present. AIB = Azuero igneous basement, APVA = Azuero primitive volcanic arc, RQF = Río Quema Formation .

Weathering and supergene oxidation processes at Cerro Quema produced two mineralized zones, an upper quartz and iron oxide zone enriched in Au and a lower supergene enrichment zone where $\mathrm{Cu}$ is concentrated.

Field observations as well as geochronologic and biostratigraphic data support a maximum lower Eocene ( $55-49 \mathrm{Ma})$ age for Cerro Quema. The deposit is interpreted to be related to the emplacement of a porphyry-like intrusion associated with the Valle Rico batholith.

The formation of Cerro Quema in the lower Eocene fore arc has important implications for exploration in the Panamanian volcanic arc and elsewhere. Our results suggest that high sulfidation deposits can form in a fore-arc environment if acidic intrusions are emplaced between the volcanic arc front and 
the trench. Exploration for high sulfidation epithermal deposits in the Azuero Peninsula should therefore be focused in the Cretaceous fore-arc sequence, especially in the Río Quema Formation dacite domes, targeting E-trending regional faults (parallel to the Río Joaquín fault zone) and lower Eocene acidic intrusions (Valle Rico-like intrusions). This implies a potential zone about $\sim 70 \times 10 \mathrm{~km}$ for hosting porphyryrelated high sulfidation epithermal deposits (Fig. 14). These findings should also be considered when exploring for high sulfidation deposits in geologically similar terranes globally.

\section{Acknowledgments}

This study is part of the first author's Ph.D., performed within the framework of the Ph.D. program in geology of the Universitat Autònoma de Barcelona. The research was supported through the research project CGL2007-62690/BTE (Spanish Ministry of Science and Education), and a by a predoctoral grant from the Departament d'Universitats, Recerca i Societat de la Informació (Generalitat de Catalunya). The corresponding author would like to express his gratitude to the SEG Foundation and the SEG Canada Foundation for the 2009, 2010, and 2011 Hugh E. McKinstry student research grants, which paid for part of the field and related laboratory research expenses. We thank Bellhaven Copper and Gold Inc. for access to mine samples and drill cores used in this study. Discussions and fieldwork comments on the Cerro Quema deposit geology from Carl E. Nelson and Stewart D. Redwood were very fruitful and are greatly appreciated. We want to thank Jose Berrenenchea and Juan D. Martín-Martín for the supervision of the clay separation work and XRD interpretation, respectively. Help from and discussions with Xavier Llovet and Flora Boekhout about EMPA analyses and $\mathrm{Ar} / \mathrm{Ar}$ data interpretation, respectively, are specially appreciated. Finally, we would like to express our gratitude to Dr. David R. Cooke, Dr. Peter Hollings, and Dr. Huayong Chen for their comments and critical revision of the manuscript, which contributed to a substantial improvement.

\section{REFERENCES}

Aoki, M., Comsti, E.C., Lazo, F.B., and Matsuhisa, Y., 1993, Advanced argillic alteration and geochemistry of alunite in an evolving hydrothermal system at Baguio, northern Luzon, Philippines: Resource Geology, v. 43, p. 155-164.

Arribas, A., 1995, Characteristics of high-sulfidation epithermal deposits, and their relation to magmatic fluid: Mineralogical Association of Canada Short Course, v. 23, p. 419-454.
Arribas, A., and Tosdal, R.M., 1994, Isotopic composition of Pb in ore deposits of the Betic Cordillera, Spain; origin and relationship to other European deposits: Economic Geology, v. 89, p. 1074-1093.

Arribas, A., Cunningham, C.G., Rytuba, J.J., Rye, R.O., Kelly, W.C., Podwysocki, M.H., McKee, E.H., and Tosdal, R.M., 1995a, Geology, geochronology, fluid inclusions, and isotope geochemistry of the Rodalquilar gold alunite deposit, Spain: Economic Geology, v. 90, p. 795-822.

Arribas, A., Hedenquist, J.W., Itaya, T., Okada, T., Concepcion, R.A., and Garcia, Fr., J.S., 1995b, Contemporaneous formation of adjacent porphyry and epithermal $\mathrm{Cu}-\mathrm{Au}$ deposits over $300 \mathrm{ka}$ in northern Luzon, Philippines: Geology, v. 23, p. 337-340.

Bajwah, Z.U., Seccombe, P.K., and Offler, R., 1987, Trace element distribution, Co:Ni ratios and genesis of the Big Cadia iron-copper deposit, New South Wales, Australia: Mineralium Deposita, v. 22, p. 292-300.

Barat, F., Maurin, T., Auxierte, J.-L., Mercier de Lépinay, B., Salmon, P., and Sosson, M., 2012, Cenozoic tectonic evolution leading to the Choco-South America collision (Panama-Colombia), from seismic profiles interpretations: American Geophysical Union, AGU Fall Meeting, San Francisco, CA, December 3-7, 2012, Poster T41A-2577.

Barat, F., Mercier de Lépinay, B., Sosson, M., Müller, C., Baumgartner, P.O., and Baumgartner-Mora, C., 2014, Transition from the Farallon plate subduction to the collision between South and Central America: Geological evolution of the Panama Isthmus: Tectonophysics, v. 622, p. 145-167.

Barckhausen, U., Ranero, C.R., von Huene, R., Cande, S.C., and Roeser, H.A., 2001, Revised tectonic boundaries in the Cocos Plate off Costa Rica; implications for the segmentation of the convergent margin and for plate tectonic models: Journal of Geophysical Research, v. 106, p. 19,207-19,220.

Berger, B.R., and Henley, R.W., 1989, Advances in the understanding of epithermal gold-silver deposits, with special reference to the western United States: Economic Geology Monograph 6, p. 405-423.

Binns, R.A., and Scott, S.D., 1993, Actively forming polymetallic sulfide deposits associated with felsic volcanic rocks in the eastern Manus back-arc basin, Papua New Guinea: Economic Geology, v. 88, p. 2226-2236.

Bourgois, J., Azema, J., Tournon, J., Bellon, H., Calle, B., Parra, E., Toussaint, J.-F., Gla\{Barat, 2014 \#355\}\{Barat, $2014 \# 355\}$ çon, G., Feinberg, H., De Wever, P., and Orgilia, I., 1982, Age et structures des complexes basiques et ultrabasiques de la façade pacifique entre $3^{\circ} \mathrm{N}$ et $12^{\circ} \mathrm{N}$ (Colombie, Panama et Costa Rica): Bulletin de la Société Géologique de France, v. 24 , p. $545-554$.

Bove, D.J., Rye, R.O., and Hon, K., 1990, Evolution of the Red Mountain alunite deposit, Lake City, Colorado: U. S. Geological Survey, Open File Report 90-0235, 29 p.

Bralia, A., Sabatini, G., and Troja, F., 1979, A revaluation of the Co/Ni ratio in pyrite as geochemical tool in ore genesis problems; evidences from southern Tuscany pyritic deposits: Mineralium Deposita, v. 14, p. 353-374.

Brill, B.A., 1989, Trace-element contents and partitioning of elements in ore minerals from the CSA Cu-Pb-Zn deposit, Australia, and implications for ore genesis: Canadian Mineralogist, v. 27, p. 263-274.

Buchs, D.M., 2008, Late Cretaceous to Eocene geology of the South Central American forearc area (southern Costa Rica and western Panama): Initiation and evolution of an intra-oceanic convergent margin: Unpublished Ph.D. thesis, Lausanne, Switzerland, Université de Lausanne, $230 \mathrm{p}$.

Buchs, D.M., Baumgartner, P.O., Baumgartner Mora, C., Bandini, A.N., Jackett, S.-J., Diserens, M.-O., and Stucki, J., 2009, Late Cretaceous to

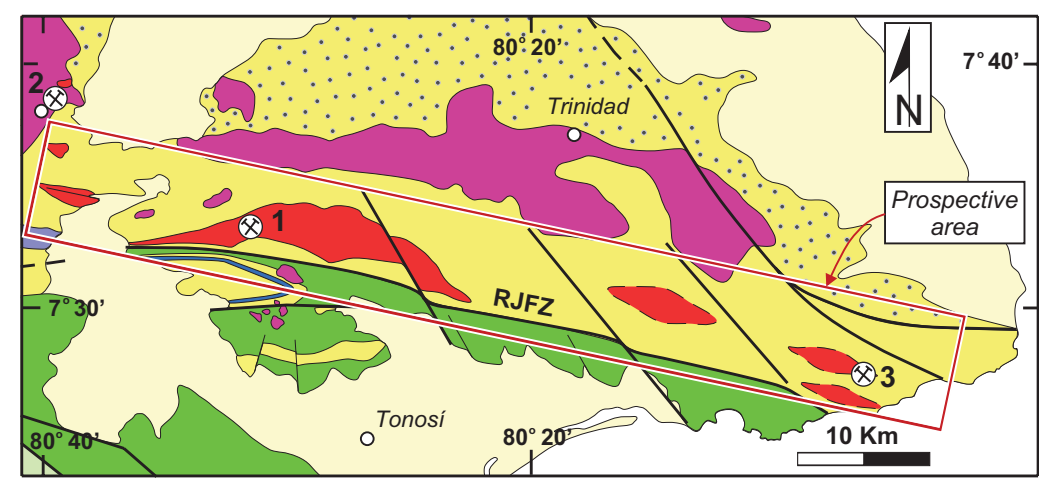

Fig. 14. Prospective area for porphyry-related high sulfidation epithermal deposits in the Azuero Peninsla. See Figure 1 for reference. RJFZ = Río Joaquín fault zone. 1) Cerro Quema deposit, 2) Pitaloza prospect, 3) Juan Díaz prospect. 
Miocene seamount accretion and melange formation in the Osa and Burica peninsulas (southern Costa Rica); episodic growth of a convergent margin: Geological Society Special Publications, v. 328, p. 411-456.

Buchs, D.M., Arculus, R.J., Baumgartner, P.O., Baumgartner-Mora, C., and Ulianov, A., 2010, Late Cretaceous arc development on the SW margin of the Caribbean plate: Insights from the Golfito, Costa Rica, and Azuero, Panama, complexes: Geochemistry, Geophysics, Geosystems, v. 11, p. Q07S24.

Buchs, D.M., Baumgartner, P.O., Baumgartner-Mora, C., Flores, K., and Bandini, A.N., 2011a, Upper Cretaceous to Miocene tectonostratigraphy of the Azuero area (Panama) and the discontinuous accretion and subduction erosion along the Middle American margin: Tectonophysics, v. 512, p. 31-46.

Buchs, D.M., Arculus, R.J., Baumgartner, P.O., and Ulianov, A., 2011b, Oceanic intraplate volcanoes exposed: Example from seamounts accreted in Panama: Geology, v. 39, p. 335-338.

Chang, Z., Hedenquist, J.W., White, N.C., Cooke, D.R., Deyell, C.L. and Garcia, J., 2009, New tools for exploring lithocaps: Example from Mankayan intrusion-centered Cu-Au district, Philippines: Society for Geology Applied to Mineral Deposits, SGA Biennial Meeting, 10 ${ }^{\text {th }}$, Townsville, North Queensland, August 17-20, 2009, Proceedings, p. 707-709.

Chang, Z., Hedenquist, J.W., White, N.C., Cooke, D.R., Roach, M., Deyell, C.L., Garcia, J., Gemmell, J.B., McKnight, S., and Cuison, A.L., 2011, Exploration tools for linked porphyry and epithermal deposits: Example from the Mankayan intrusion-centered $\mathrm{Cu}$-Au district, Luzon, Philippines: Economic Geology, v. 106, p. 1365-1398.

Coates, A.G., Collins, L.S., Aubry, M.-P., and Berggren, W.A., 2004, The geology of the Darien, Panama, and the late Miocene-Pliocene collision of the Panama arc with northwestern South America: Geological Society of America Bulletin, v. 116, p. 1327-1344.

Cooke, D.R., and Simmons, S.F., 2000, Characteristics and genesis of epithermal gold deposits: Reviews in Economic Geology, v. 13, p. 221-244.

Corbett, G.J., and Leach, T.M., 1998, Southwest Pacific Rim gold-copper systems: Structure, alteration, and mineralization: Society of Economic Geologists, Special Publication 6, 236 p.

Corral, I., 2013, Geology and metallogeny of the Cerro Quema Au-Cu deposit (Azuero Peninsula, Panama): Unpublished Ph.D. thesis, Barcelona, Spain, Universitat Autònoma de Barcelona, $211 \mathrm{p}$.

Corral, I., Griera, A., Gómez-Gras, D., Corbella, M., Canals, À., Pineda-Falconett, M., and Cardellach, E., 2011a, Geology of the Cerro Quema Au-Cu deposit (Azuero Peninsula, Panama): Geologica Acta, v. 9, p. 481-498.

Corral, I., Cardellach, E., Corbella, M., Canals, À., and Johnson, C.A., 2011b, Origin and evolution of fluids associated with the Cerro Quema $\mathrm{Au}-\mathrm{Cu}$ deposit (Azuero Peninsula, Panama): Evidence from microthermometry, $\mathrm{O}, \mathrm{H}$ and S isotopes: Society for Geology Applied to Mineral Deposits, SGA Biennial Meeting, 11 th , Antofagasta, Chile, September 26-29, 2011, Proceedings, p. 178-180

Corral, I., Gómez-Gras, D., Griera, A., Corbella, M., and Cardellach, E., 2013, Sedimentation and volcanism in the Panamanian Cretaceous intraoceanic arc and fore-arc: New insights from the Azuero Peninsula (SW Panama): Bulletin de la Société Géologique de France, v. 184, p. 35-45.

Dalrymple, G.B., Alexander, Jr., E.C., Lanphere, M.A., and Kraker, G.P., 1981, Irradiation of samples for ${ }^{40} \mathrm{Ar} /{ }^{39} \mathrm{Ar}$ dating using the Geological Survey TRIGA reactor: U.S. Geological Survey Professional Paper 1176, 55 p.

Del Giudice, D., and Recchi, G., 1969, Geologia del area del Proyecto Minero de Azuero., Informe técnico preparado para el gobierno de la República de Panamá por las Naciones Unidas, actuando y participando como agencia ejecutora: Gobierno de la República de Panamá, 48 p.

de Ronde, C.E.J., Massoth, G.J., Barker, E.T., and Lupton, J.E., 2003, Submarine hydrothermal venting related to volcanic arcs: Society of Economic Geologists, Special Publication 10, p. 91-110.

Deyell, C.L., and Hedenquist, J.W., 2011, Trace element geochemistry of enargite in the mankayan district, Philippines: Economic Geology, v. 106, p. $1465-1478$

Deyell, C.L., Leonardson, R., Rye, R.O., Thompson, J.F.H., Bissig, T., and Cooke, D.R., 2005a, Alunite in the Pascua-Lama high-sulfidation deposit: Constraints on alteration and ore deposition using stable isotope geochemistry: Economic Geology, v. 100, p. 131-148.

Deyell, C.L., Rye, R.O., Landis, G.P., and Bissig, T., 2005b, Alunite and the role of magmatic fluids in the Tambo high-sulfidation deposit, El IndioPascua Belt, Chile: Chemical Geology, v. 215, p. 185-218.

Dill, H.G., 2003, A comparative study of APS minerals of the Pacific Rim fold belts with special reference to South American argillaceous deposits: Journal of South American Earth Sciences, v. 16, p. 301-320.
Dirección General de Recursos Minerales (DGRM), 1976, Panama geologic map (mapa Geológico de Panamá): Panama City, DGRM, scale 1:500,000. Duque-Caro, H., 1990, Neogene stratigraphy, paleoceanography and paleobiogeography in northwest South America and the evolution of the Panama Seaway: Palaeogeography, Palaeoclimatology, Palaeoecology, v. 77, p. 203-234.

Edwards, A.B., and Carlos, G.C., 1954, The selenium content of some Australian sulphide deposits: Proceedings-Australasian Institute of Mining and Metallurgy, v. 172, p. 31-63.

Embley, R.W., Baker, E.T., Chadwick, Jr., W.W., Lupton, J.E., Resing, K.A., Massoth, G.J., and Nakamura, K., 2004, Explorations of Mariana arc volcanoes reveal new hydrothermal systems: Eos, v. 85, p. 37, 40.

Ferencic, A., 1971, Metallogenic provinces and epochs in southern Central America: Mineralium Deposita, v. 6, p. 77-88.

Fintor, K., Tóth, T.M., and Schubert, F., 2011, Hydrothermal palaeofluid circulation in the fracture network of the Baksa Gneiss Complex of SW Pannonian Basin, Hungary: Geofluids, v. 11, p. 144-165.

Fitzpatrick, A.J., 2008, The measurements of Se/S ratios in sulphide minerals and their application to ore deposits studies: Unpublished Ph.D. thesis, Kingston, Canada, Queen's University, p. 188.

Goldschmidt, V.M., 1954, Geochemistry: London: Oxford University Press, $730 \mathrm{p}$.

Hannington, M.D., and Herzig, P.M., 1993, Shallow submarine hydrothermal systems in modern island arc settings: Geological Association of Canada Annual Meeting, Edmonton, 1993, Program and Abstracts, v. 19, p. A40.

Harmon, R.S., 2005, Geological development of Panama: Water Science and Technology Library, v. 52, p. 45-62.

Hauff, F., Hoernle, K., van den Bogaard, P., Alvarado, G., and Garbe-Schönberg, D., 2000, Age and geochemistry of basaltic complexes in western Costa Rica; contributions to the geotectonic evolution of Central America: Geochemistry, Geophysics, Geosystems, v. 1, p. 1009.

Hawley, J.E., and Nichol, I., 1959, Selenium in some Canadian sulfides: Economic Geology, v. 54, p. 608-628.

Hedenquist, J.W., 1987, Mineralization associated with volcanic-related hydrothermal systems in the Circum-Pacific basin: Transactions of the Circum-Pacific Energy and Mineral Resources Conference, v. 4, p. 513-524.

Hedenquist, J.W., and Lowenstern, J.B., 1994, The role of magmas in the formation of hydrothermal ore deposits: Nature, v. 370, p. 519-527.

Hedenquist, J.W., Matsuhisa, Y., Izawa, E., White, N.C., Giggenbach, W.F., and Aoki, M., 1994, Geology, geochemistry, and origin of high sulfidation $\mathrm{Cu}-\mathrm{Au}$ mineralization in the Nansatsu district, Japan: Economic Geology, v. 89 , p. $1-30$.

Hedenquist, J.W., Arribas, A., and Gonzalez-Urien, E., 2000, Exploration for epithermal gold deposits: Reviews in Economic Geology, v. 13, p. 245-277.

Hernandez, P.A., Garcia-Estrada, P.A., Cowley, P.N., and Gallagher, M.J., 1989, Geological setting, alteration and lithogeochemistry of the Transaccion epithermal gold deposit, Rodalquilar mining district, southeast Spain Institution of Mining and Metallurgy Transactions, Sec. B, v. 98, p. 78-80.

Hoernle, K., and Hauff, F., 2007, Oceanic igneous complexes, in Bundschuh, J., and Alvarado, G., eds., Geology of Central America: Leiden, The Netherlands, Taylor and Francis, p. 523-547.

Hoernle, K., van den Bogaard, P., Werner, R., Lissinna, B., Hauff, F. Alvarado, G., and Garbe-Schonberg, D., 2002, Missing history (16-71 Ma) of the Galapagos hotspot: Implications for the tectonic and biological evolution of the Americas: Geology, v. 30, p. 795-798.

Hoernle, K., Hauff, F., and van den Bogaard, P., 2004, 70 m.y. history (139-69 Ma) for the Caribbean large igneous province: Geology, v. 32, p. 697-700.

Huston, D.L., Sie, S.H., Suter, G.F., Cooke, D.R., and Both, R.A., 1995 , Trace elements in sulfide minerals from eastern Australian volcanic-hosted massive sulfide deposits; Part I, Proton microprobe analyses of pyrite, chalcopyrite, and sphalerite, and Part II, Selenium levels in pyrite; comparison with $\delta^{34} \mathrm{~S}$ values and implications for the source of sulfur in volcanogenic hydrothermal systems: Economic Geology, v. 90, p. 1167-1196.

Itaya, T., Arribas, A., and Okada, T., 1996, Argon release systematics of hypogene and supergene alunite based on progressive heating experiments from 100 to $1000^{\circ} \mathrm{C}$ : Geochimica et Cosmochimica Acta, v. 60, p. $4525-4535$.

Keigwin, Jr., L.D., 1978, Pliocene closing of the Isthmus of Panama, based on biostratigraphic evidence from nearby Pacific Ocean and Caribbean Sea cores: Geology, v. 6, p. 630-634.

Kellogg, J.N., Vega, V., Stallings, T.C., and Aiken, C.L.V., 1995, Tectonic development of Panama, Costa Rica, and the Colombian Andes; constraints from global positioning system geodetic studies and gravity: Geological Society of America Special Paper, v. 295, p. 75-90 
Kesler, S.E., 1978, Metallogenesis of the Caribbean region: Journal of the Geological Society, v. 135, p. 429-441.

Kesler, S.E., Sutter, J.F., Issigonis, M.J., Jones, L.M., and Walker, R.L., 1977, Evolution of porphyry copper mineralization in an oceanic island arc; Panama: Economic Geology, v. 72, p. 1142-1153.

Kesler, S.E., Russell, N., and McCurdy, K., 2003, Trace-metal content of the Pueblo Viejo precious-metal deposits and their relation to other high-sulfidation epithermal systems: Mineralium Deposita, v. 38, p. 668-682.

Kolarsky, R.A., Mann, P., Monechi, S., Meyerhoff-Hull, D., and Pessagno, E.A., 1995, Stratigraphic development of southwestern Panama as determined from integration of marine seismic data and onshore geology: Geological Society of America Special Paper, v. 295, p. 159-200.

Krawinkel, H., Wozazek, S., Krawinkel, J., and Hellmann, W., 1999, Heavymineral analysis and clinopyroxene geochemistry applied to provenance analysis of lithic sandstones from the Azuero-Sona Complex (NW Panama): Sedimentary Geology, v. 124, p. 149-168.

Krawinkel, J., and Seyfried, H., 1994, Struktur and kinematic im fore-arc der suedlichen zentralamerikanischen landbruecke: Bonn, Terra Nostra, v. 2, p. $47-49$.

Levy, E., 1970, La metalogenesis en America Central: Instituto Centroamericano de Investigación y Tecnología Industrial, v. 3, p. 17-57.

Lissinna, B., 2005, A profile through the Central American land bridge in western Panama: 115 Ma interplay between the Galápagos hotspot and the Central American subduction zone: Unpublished Ph.D. thesis, Germany, Fakultät der Christian-Alberchts-Universität zu Kiel, 102 p.

Lissinna, B., Hoernle, K., and van den Bogaard, P., 2002, Northern migration of arc volcanism in western Panama; evidence for subduction erosion?: Eos, v. 83 , p. $1463-1464$

Loftus-Hills, G., and Solomon, M., 1967, Cobalt, nickel and selenium in sulphides as indicators of ore genesis: Mineralium Deposita, v. 2, p. 228-242.

Lonsdale, P., 2005, Creation of the Cocos and Nazca plates by fission of the Farallon plate: Tectonophysics, v. 404, p. 237-264.

Montes, C., Bayona, G.A., Cardona, A., Buchs, D.M., Silva, C.A., Morón, S.E., Hoyos, N., Ramírez, D.A., Jaramillo, C.A., and Valencia, V., 2012, Arccontinent collision and orocline formation: Closing of the Central American seaway: Journal of Geophysical Research, v. 117, B04105, 25 p.

Nelson, C.E., 1995, Porphyry copper deposits of southern Central America: Arizona Geological Society Digest, v. 20, p. 553-565.

2007, Metallic mineral resources, in Bundschuh, J., and Alvarado, G.E., eds., Central America; geology, resources and hazards: The Netherlands, Taylor and Francis, p. 885-915.

Nelson, C.E., and Nietzen, F., 2000, Metalogenia del oro y cobre en América Central: Revista Geológica de América Central., v. 23, p. 25-41.

Pindell, J.L., and Kennan, L., 2009, Tectonic evolution of the Gulf of Mexico, Caribbean and northern South America in the mantle reference frame: An update: Geological Society Special Publications, v. 328, p. 1-55.

Price, B.J., 1972, Minor elements in pyrites from the Smithers map area, B.C., and exploration applications of minor element studies: Department of Geological Sciences, University of British Columbia, Report, v. 13, p. 32-33.

Puritch, E.J., Sutcliffe, R.H., Wu, Y., Armstrong, T., and Yassa, A., 2012, NI 43-101 technical report and mineral resource estimate on the Cerro Quema Project, Los Santos province, Panama: Prepared for Preshimco Resources Inc., by P\&E Mining Consultants Inc., 123 p., www.sedar.com/GetFile. do?lang $=\mathrm{EN} \&$ docClass $=24 \&$ issuer $\mathrm{No}=00011899 \&$ fileName $=/ \mathrm{csfsprod} /$ data136/filings/01976730/00000001/g\%3A\%5CPERSHIMCO143-101.pdf.

Raymond, O.L., 1996, Pyrite composition and ore genesis in the Prince Lyell copper deposit, Mt Lyell mineral field, western Tasmania, Australia: Ore Geology Reviews, v. 10, p. 231-250.

Recchi, G., and Miranda, R., 1977, Calizas de los Planes-Guaniquito (Tonosí): Panama City, Dirección General de Recursos Minerales, Technical Report, p. 27.

Roberts, R.J., and Irving, M., 1957, Mineral deposits of Central America: U.S. Geological Survey Bulletin 1034, 205 p.

Sillitoe, R.H., 1989, Gold deposits in western Pacific island arcs; the magmatic connection: Economic Geology Monograph 6, p. 274-291.
1993, Epithermal models; genetic types, geometrical controls and shallow features: Geological Association of Canada Special Paper 40, p. $403-417$.

1995, Exploration of porphyry copper lithocaps: Australasian Institute of Mining and Metallurgy, v. 9/95, p. 527-532.

1999, Styles of high-sulphidation gold, silver and copper mineralisation in porphyry and epithermal environments: Australasian Institute of Mining and Metallurgy, v. 4-99, p. 29-44.

2010, Porphyry copper systems: Economic Geology, v. 105, p. 3-41.

Sillitoe, R.H., Baker, E.M., and Brook, W.A., 1984, Gold deposits and hydrothermal eruption breccias associated with a maar volcano at Wau, Papua New Guinea: Economic Geology, v. 79, p. 638-655.

Speidel, F., Faure, S., Smith, M.T., and McArthur, G.F., 2001, Exploration and discovery at the Petaquilla copper-gold concession, Panama: Society of Economic Geologists, Special Publication 8, p. 349-362.

Stern, R.J., 2010, The anatomy and ontogeny of modern intra-oceanic arc systems: Geological Society Special Publication, v. 338, p. 7-34

Stern, R.J., and Bloomer, S.H., 1992, Subduction zone infancy: Examples from the Eocene Izu-Bonin-Mariana and Jurassic California arcs: Geological Society of America Bulletin, v. 104, p. 1621-1636.

Stern, R.J., Reagan, M., Ishizuka, O., Ohara, Y., and Whattam, S., 2012, To understand subduction initiation, study forearc crust: To understand forearc crust, study ophiolites: Lithosphere, v. 4, p. 469-483.

Steven, T.A., and Ratté, J.C., 1960, Geology and ore deposits of the Summitville district, San Juan Mountains, Colorado: U.S. Geological Survey Professional Paper 343, p. 70.

Stoffregen, R.E., 1987, Genesis of acid-sulfate alteration and $\mathrm{Au}-\mathrm{Cu}-$ Ag mineralization at Summitville, Colorado: Economic Geology, v. 82, p. $1575-1591$.

Stoffregen, R.E., and Alpers, C.N., 1987, Woodhouseite and svanbergite in hydrothermal ore deposits; products of apatite destruction during advanced argillic alteration: Canadian Mineralogist, v. 25, part 2, p. 201-211.

Trenkamp, R., Kellogg, J.N., Freymueller, J.T., and Mora, H.P., 2002, Wide plate margin deformation, southern Central America and northwestern South America, CASA GPS observations: Journal of South American Earth Sciences, v. 15, p. 157-171.

Valiant, W.W., Collins, S.E., and Krutzelmann, H., 2011, NI 43-101 technical report on the Cerro Quema Project, Panama: Prepared for Preshimco Resources Inc., by Scott Wilson Roscoe Postle Associates Inc., 109 p., www. sedar.com/GetFile.do?lang=EN\&docClass $=24 \&$ issuerNo $=00011899 \&$ file Name $=/$ csfsprod/data118/filings/01748861/00000001/g\%3A\%5CPERSHI MCO\%5CPERSHIMCOrapporttechupdate.pdf.

Wegner, W., Worner, G., Harmon, R.S., and Jicha, B.R., 2011, Magmatic history and evolution of the Central American land bridge in Panama since Cretaceous times: Geological Society of America Bulletin, v. 123, p. 703-724.

Werner, R., Hoernle, K., Barckhausen, U., and Hauff, F., 2003, Geodynamic evolution of the Galapagos hot spot system (central East Pacific) over the past 20 m.y.; constraints from morphology, geochemistry, and magnetic anomalies: Geochemistry, Geophysics, Geosystems, v. 4, p. 1108.

Weyl, R., 1980, Geology of Central America, $2^{\text {nd }}$ edition: Berlin, Gebrueder Borntraeger, $371 \mathrm{p}$.

White, N.C., 1991, High sulfidation epithermal gold deposits; characteristics and a model for their origin: Geological Survey of Japan Report 227, p. 9-20.

1993, Geology and mineralization of the Santa Rosa gold deposits, Panama: Society of Mining Engineers, Preprint Series, 5 p.

Wleklinski, S., 1969, Gold deposits of northern Veraguas: United Nations Development Program, Mineral Survey of the Azuero Area, v. 1, $113 \mathrm{p}$

Woakes, E.R., 1923, The Darien gold mine, Panama: Mining Magazine, v. 29, p. 270-278.

Wörner, G., Harmon, R.S., and Wegner, W., 2009, Geochemical evolution of igneous rocks and changing magma sources during the formation and closure of the Central American land bridge of Panama: Backbone of the Americas: Shallow subduction, plateau uplift, and ridge terrane collision: Geological Society of America Memoir 204, p. 183-196. 


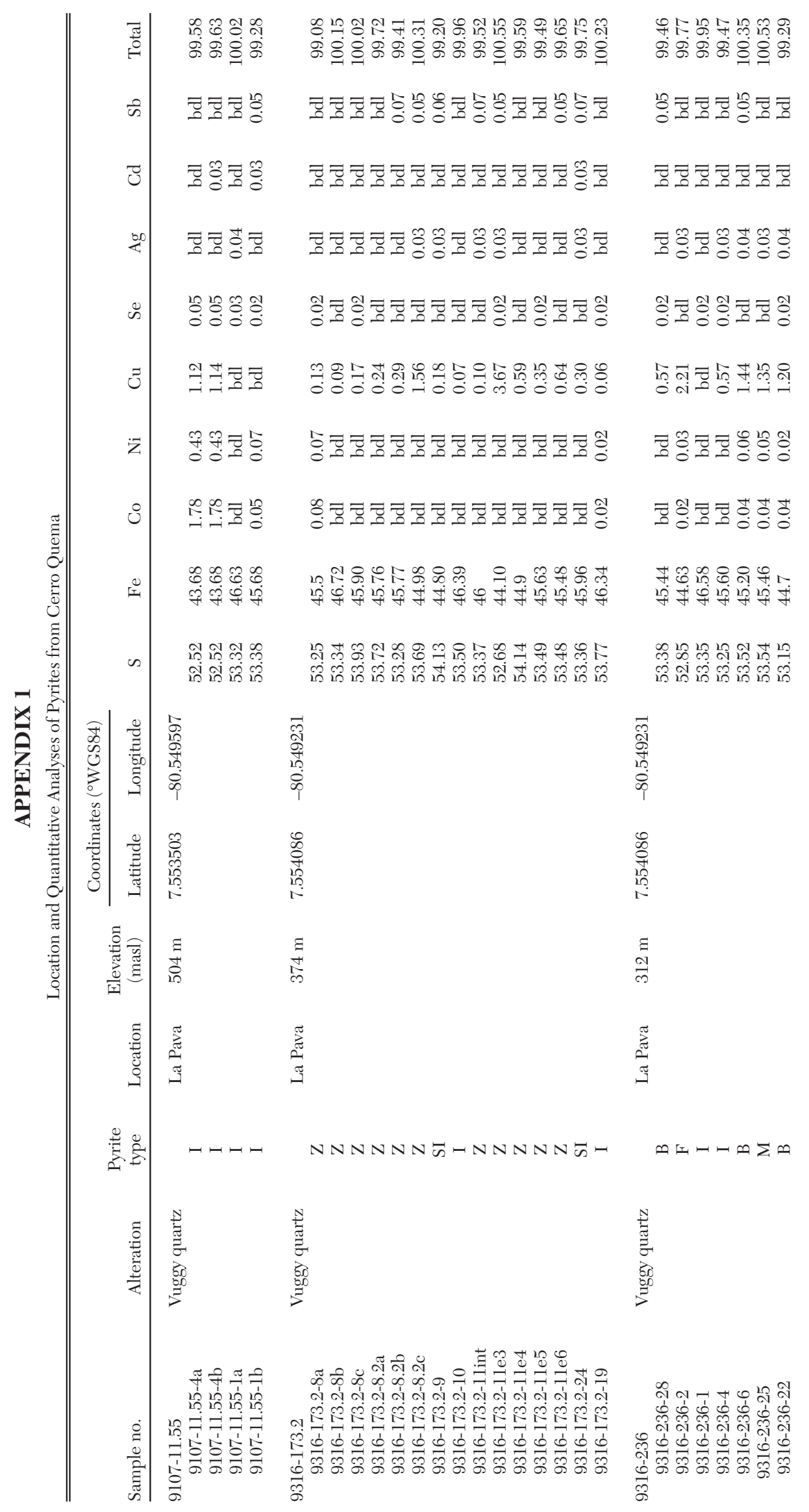




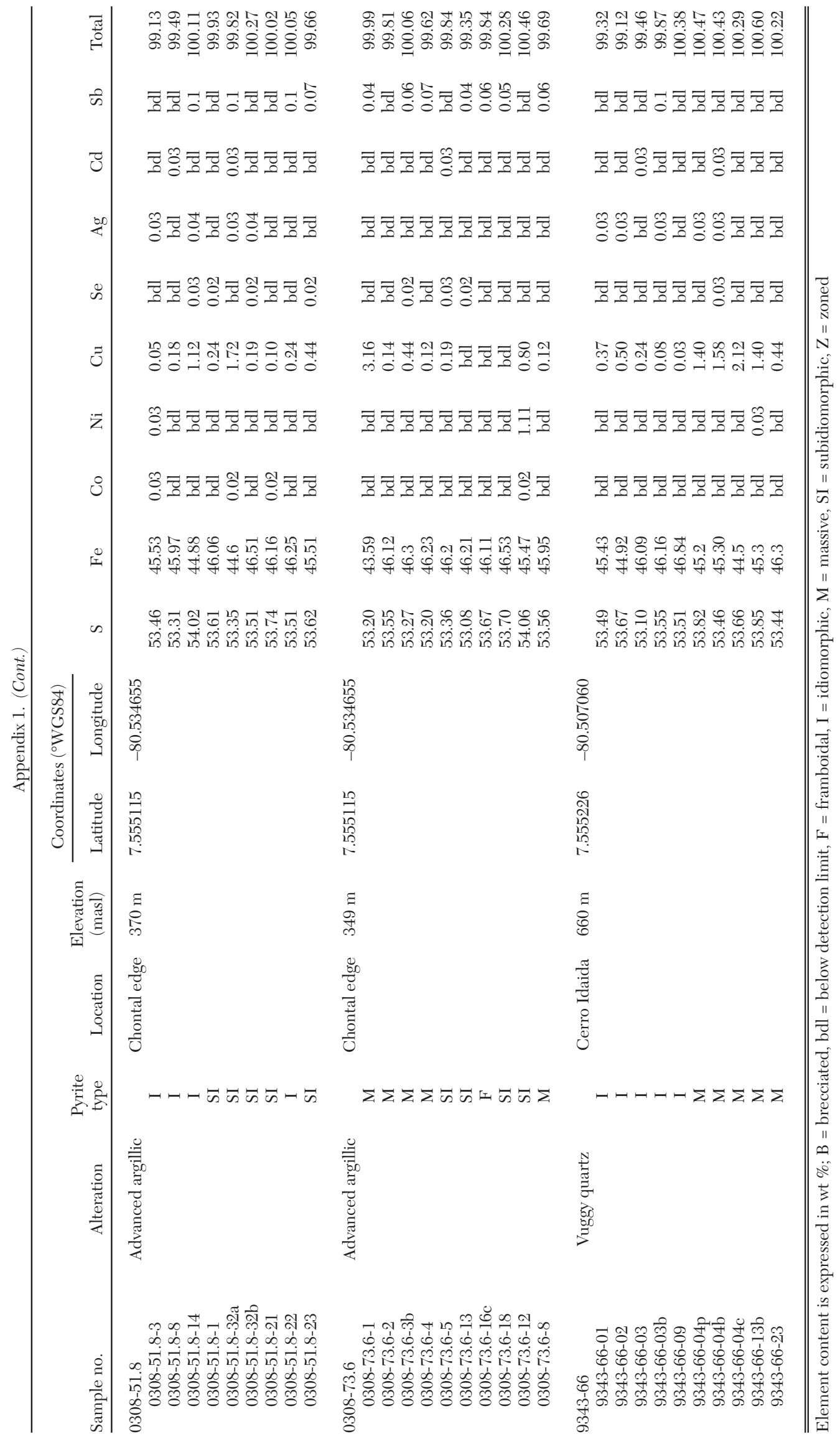




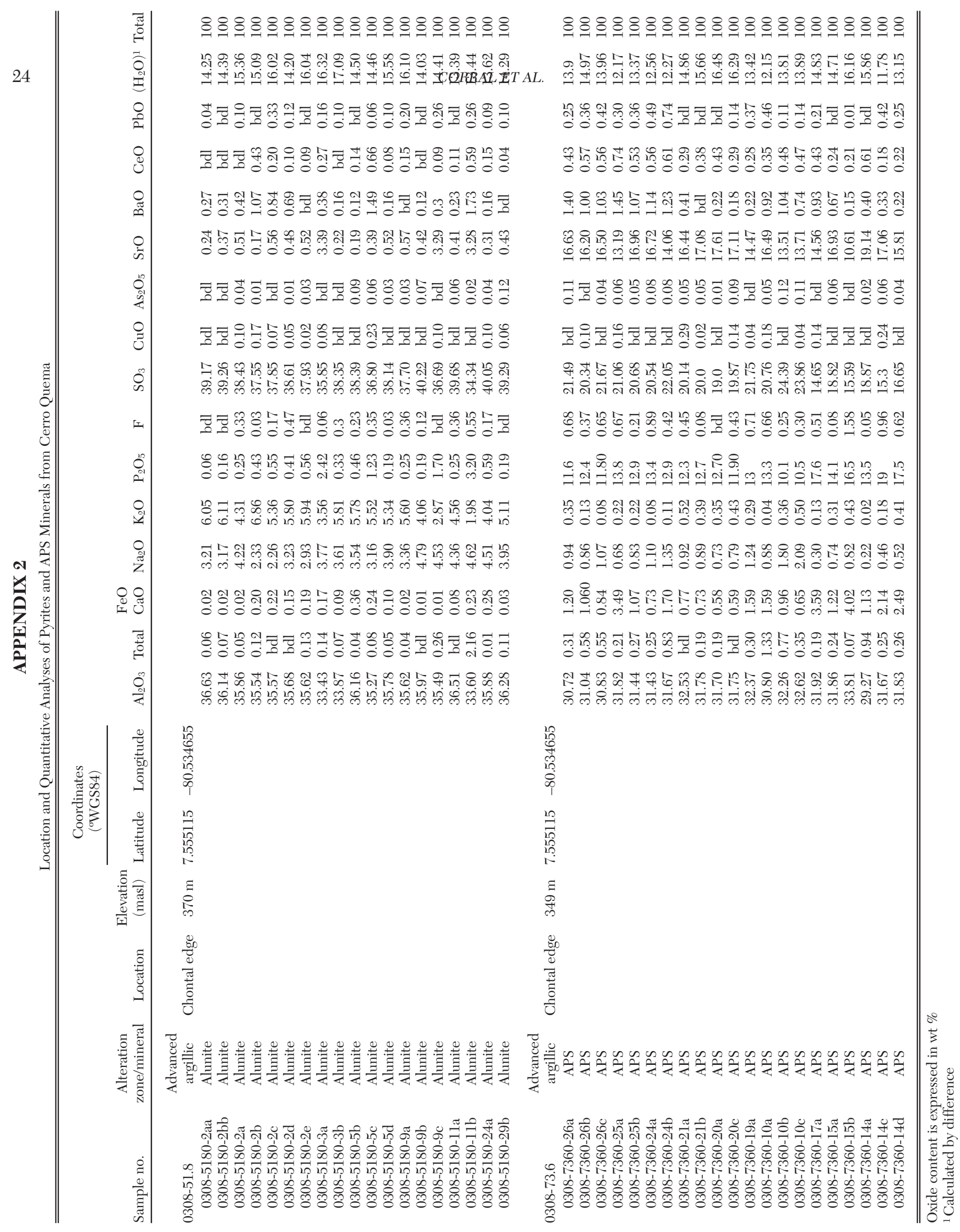

